\title{
Formation of secondary aerosols from gasoline vehicle exhaust when mixing with $\mathrm{SO}_{2}$
}

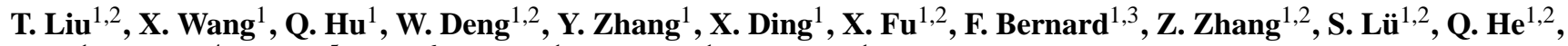 \\ X. Bi ${ }^{1}$, J. Chen ${ }^{4}$, Y. Sun ${ }^{5}$, J. Yu ${ }^{6}$, P. Peng ${ }^{1}$, G. Sheng ${ }^{1}$, and J. Fu ${ }^{1}$ \\ ${ }^{1}$ State Key Laboratory of Organic Geochemistry, Guangzhou Institute of Geochemistry, Chinese Academy of Sciences, \\ Guangzhou 510640, China \\ ${ }^{2}$ University of Chinese Academy of Sciences, Beijing 100049, China \\ ${ }^{3}$ Chemical Sciences Division, NOAA Earth System Research Laboratory, Boulder, Colorado 80305, USA \\ ${ }^{4}$ Shanghai Key Laboratory of Atmospheric Particle Pollution and Prevention, Department of Environmental Science \& \\ Engineering, Fudan University, Shanghai 200433, China \\ ${ }^{5}$ Institute of Atmospheric Physics, Chinese Academy of Sciences, Beijing 100029, China \\ ${ }^{6}$ Division of Environment, Hong Kong University of Science \& Technology, Clear Water Bay, Kowloon, Hong Kong, China
}

Correspondence to: X. Wang (wangxm@gig.ac.cn)

Received: 6 August 2015 - Published in Atmos. Chem. Phys. Discuss.: 2 September 2015

Revised: 16 December 2015 - Accepted: 7 January 2016 - Published: 21 January 2016

\begin{abstract}
Sulfur dioxide $\left(\mathrm{SO}_{2}\right)$ can enhance the formation of secondary aerosols from biogenic volatile organic compounds (VOCs), but its influence on secondary aerosol formation from anthropogenic VOCs, particularly complex mixtures like vehicle exhaust, remains uncertain. Gasoline vehicle exhaust (GVE) and $\mathrm{SO}_{2}$, a typical pollutant from coal burning, are directly co-introduced into a smog chamber, in this study, to investigate the formation of secondary organic aerosols (SOA) and sulfate aerosols through photooxidation. New particle formation was enhanced, while substantial sulfate was formed through the oxidation of $\mathrm{SO}_{2}$ in the presence of high concentration of $\mathrm{SO}_{2}$. Homogenous oxidation by $\mathrm{OH}$ radicals contributed a negligible fraction to the conversion of $\mathrm{SO}_{2}$ to sulfate, and instead the oxidation by stabilized Criegee intermediates (sCIs), formed from alkenes in the exhaust reacting with ozone, dominated the conversion of $\mathrm{SO}_{2}$. After $5 \mathrm{~h}$ of photochemical aging, GVE's SOA production factor revealed an increase by $60-200 \%$ in the presence of high concentration of $\mathrm{SO}_{2}$. The increase could principally be attributed to acid-catalyzed SOA formation as evidenced by the strong positive linear correlation $\left(R^{2}=0.97\right)$ between the SOA production factor and in situ particle acidity calculated by the AIM-II model. A high-resolution time-of-flight aerosol mass spectrometer (HR-TOF-AMS) resolved OA's relatively lower oxygen-to-carbon $(\mathrm{O}: \mathrm{C})(0.44 \pm 0.02)$ and
\end{abstract}

higher hydrogen-to-carbon $(\mathrm{H}: \mathrm{C})(1.40 \pm 0.03)$ molar ratios for the GVE/ $\mathrm{SO}_{2}$ mixture, with a significantly lower estimated average carbon oxidation state $\left(\mathrm{OS}_{\mathrm{c}}\right)$ of $-0.51 \pm 0.06$ than $-0.19 \pm 0.08$ for GVE alone. The relative higher mass loading of $\mathrm{OA}$ in the experiments with $\mathrm{SO}_{2}$ might be a significant explanation for the lower SOA oxidation degree.

\section{Introduction}

Sulfate and organic aerosols (OA) can lead to serious and complex air pollution (Parrish and Zhu, 2009) as the main components of fine particles or $\mathrm{PM}_{2.5}$, conveying negative effects on human health (Nel, 2005). Sulfate and OA additionally affect radiative forcing on a global scale (Andreae et al., 2005; Shindell et al., 2009). Thus, a detailed understanding of the magnitude and formation pathways of sulfate and $\mathrm{OA}$ is critical to formulate control strategies and to accurately estimate their impact on air quality and climate. Complications often arise due to missing or underestimated oxidation pathways of sulfur dioxide $\left(\mathrm{SO}_{2}\right)$ (Berglen et al., 2004), the precursor of sulfate, and the unclear formation mechanisms of secondary organic aerosols (SOA) (de Gouw et al., 2005; Heald et al., 2005; Johnson et al., 2006; Volkamer et 
al., 2006), accounting for a large fraction of OA (Zhang et al., 2007).

Recent smog chamber studies have demonstrated that the amount of SOA formed from dilute gasoline vehicle exhaust often exceeds primary OA (POA) (Nordin et al., 2013; Platt et al., 2013; Gordon et al., 2014; Liu et al., 2015). Aromatic hydrocarbons were found to be vital SOA precursors in gasoline vehicle exhaust. Up to $90 \%$ of SOA from idling Euro 14 vehicle exhaust could be attributed to aromatics (Nordin et al., 2013; Liu et al., 2015). Gordon et al. (2014) concluded that traditional precursors could fully explain the SOA production from old vehicles with model years prior to 1995 . Multiple studies have shown that modeled SOA can only explain a fraction of the measured SOA from gasoline vehicle exhaust (Platt et al., 2013; Tkacik et al., 2014). Platt et al. (2013) found that predicted SOA accounted for approximately $20 \%$ of the SOA formed from Euro 5 gasoline vehicle exhaust. Hence, more studies are needed to bridge the gap between modeled and measured SOA from gasoline vehicle exhaust. Emitted primarily from coal-fired power plants and coal-burning boilers, $\mathrm{SO}_{2}$, when mixed with gasoline vehicle exhaust containing the precursors for secondary nitrates and organic aerosols, $\mathrm{NO}_{x}$ and aromatics, may react, complicating the formation of sulfate and SOA. Alkenes present in gasoline vehicle exhaust can react with ozone to form stabilized Criegee intermediates (sCIs), recently considered to significantly oxidize $\mathrm{SO}_{2}$ and influence sulfate formation (Mauldin et al., 2012; Welz et al., 2012). On the other hand, recent smog chamber simulations indicated that $\mathrm{SO}_{2}$ could enhance SOA formation from typical biogenic precursors, such as monoterpenes and isoprene through acid-catalyzed reactions (Edney et al., 2005; Kleindienst et al., 2006; Jaoui et al., 2008), but the influence of acid-catalyzed reactions on SOA formation from aromatics still remains debatable (Cao and Jang, 2007; Ng et al., 2007). Combinations of several pure chemicals, additionally, are not fully representative of $\mathrm{SO}_{2}$ mixing, with vehicle exhaust containing thousands of gaseous and particle-phase components (Gordon et al., 2014) in the formation of secondary aerosols under real atmospheric conditions. Until now, there have been no reports about the influence of $\mathrm{SO}_{2}$ on secondary aerosol formation from complex vehicle exhaust.

Here we directly introduced pipe exhaust from light-duty gasoline vehicles (LDGVs) and $\mathrm{SO}_{2}$ into a smog chamber with a $30 \mathrm{~m}^{3}$ Teflon reactor (Wang et al., 2014) to study the production of secondary aerosols: the influence of LDGV exhaust on $\mathrm{SO}_{2}$ oxidation to form sulfate aerosols and reciprocally that of $\mathrm{SO}_{2}$ on $\mathrm{SOA}$ formation from primary organics in LDGV exhaust.

\section{Materials and methods}

\subsection{Vehicles and fuel}

In Europe, vehicle emissions are classified by "Euro standards", currently ranging from Euro 1 to Euro 6. China implemented the Euro 1, Euro 2, Euro 3, and Euro 4 emission standards in 2000, 2004, 2007, and 2012 for LDGVs, and the Euro 5 standard will be implemented in 2018. Three LDGVs were utilized in this study: one Euro 1 and two Euro 4 vehicles. They are all port-fuel-injected vehicles with model years ranging from 2002 to 2011. Further vehicle details are listed in Table 1. All vehicles were fueled with grade 93\# gasoline, which complies with the Euro 3 gasoline fuel standard. Details of the gasoline composition can be found elsewhere (Zhang et al., 2013).

\subsection{Smog chamber experiments}

Six photochemical experiments with LDGV exhaust were conducted in a $30 \mathrm{~m}^{3}$ indoor smog chamber at Guangzhou Institute of Geochemistry, Chinese Academy of Sciences (GIG-CAS). Details of the smog chamber are described in Wang et al. (2014). Briefly, black lamps (1.2 m long, $60 \mathrm{~W}$ Philips/10R BL, Royal Dutch Philips Electronics Ltd., the Netherlands) are used as a light source, providing a $\mathrm{NO}_{2}$ photolysis rate of $0.49 \mathrm{~min}^{-1}$. Two Teflon-coated fans are installed inside the reactor to guarantee thorough mixing of the introduced gas species and particles within $120 \mathrm{~s}$. Temperature and relative humidity in the reactor were controlled at approximately $25^{\circ} \mathrm{C}$ and $50 \%$, respectively. A schematic of the experiment setup is presented in Fig. 1. Eight thermocouples are placed between the enclosure and the reactor walls to control the temperature. The temperature inside the reactor (T9) was measured by a Siemens QFM2160 (Siemens AG, Germany). Vehicles were first operated on-road to warm up the three-way catalysts for a minimum of half an hour prior to introducing the vehicle exhaust. Idling vehicle exhaust was then introduced directly by two oil-free pumps (Gast Manufacturing Inc., USA) into the reactor at a flow rate of $40 \mathrm{~L} \mathrm{~min}^{-1}$. Losses of volatile organic compounds (VOCs) and particles in the transfer lines were estimated to be less than $5 \%$ (Liu et al., 2015). Prior to each experiment, the chamber was evacuated and filled with purified dry air at least 5 times, and then the reactor was flushed with purified dry air for a minimum of $48 \mathrm{~h}$ until no residual hydrocarbons, $\mathrm{O}_{3}, \mathrm{NO}_{x}$, or particles were detected in the reactor. The exhaust in the reactor was diluted by a factor of 13-94 compared to the tailpipe.

$\mathrm{SO}_{2}$ was injected by a gas-tight syringe following introduction of exhaust to create a mixing ratio of $\mathrm{SO}_{2}$ in the reactor of approximately $150 \mathrm{ppb}$ during three experiments with the three vehicles. Experiments without additional $\mathrm{SO}_{2}$ were also conducted for each vehicle for comparison, and additional $\mathrm{NO}$ was added to adjust the $\mathrm{VOC} / \mathrm{NO}_{x}$ ratios 
Table 1. Detailed information of the three LDGVs.

\begin{tabular}{lllrrrrr}
\hline ID & $\begin{array}{l}\text { Emission standard } \\
\text { class }\end{array}$ & Vehicle & $\begin{array}{r}\text { Model } \\
\text { year }\end{array}$ & $\begin{array}{r}\text { Mileage } \\
(\mathrm{km})\end{array}$ & $\begin{array}{r}\text { Displacement } \\
\left(\mathrm{cm}^{3}\right)\end{array}$ & $\begin{array}{r}\text { Power } \\
(\mathrm{kW})\end{array}$ & $\begin{array}{r}\text { Weight } \\
(\mathrm{kg})\end{array}$ \\
\hline I & Euro 4 & Golf & 2011 & 25000 & 1598 & 77 & 1295 \\
II & Euro 4 & Sunny & 2011 & 9448 & 1498 & 82 & 1069 \\
III & Euro 1 & Accord & 2002 & 237984 & 2298 & 110 & 1423 \\
\hline
\end{tabular}

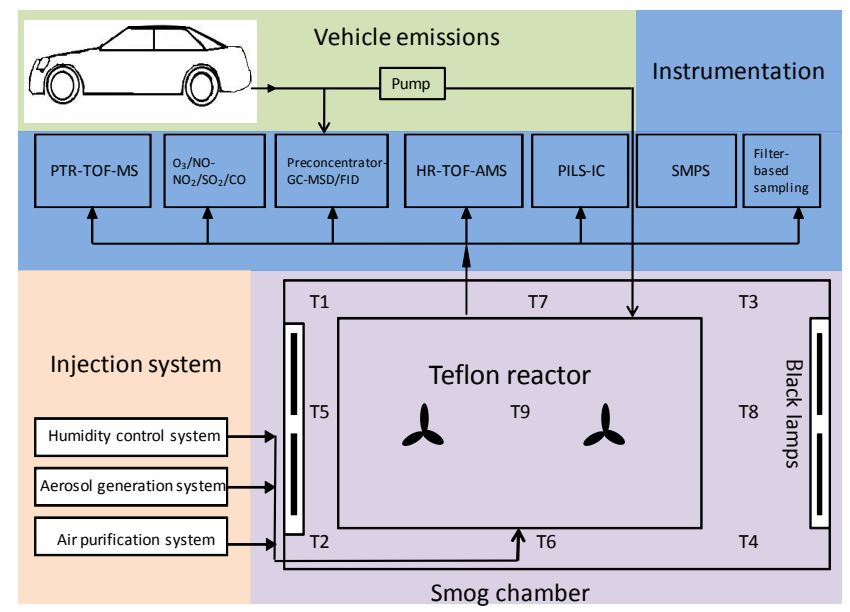

Figure 1. Schematic of the GIG-CAS smog chamber facility and vehicle exhaust injection system.

(ppb / ppb) to between 4.9 and 10.8 (Table 2). $\mathrm{VOC} / \mathrm{NO}_{x}$ ratios in experiments with the same vehicle were similar with initial concentrations of $\mathrm{NO}_{x}$ ranging from 300.8 to $458.5 \mathrm{ppb}$. After more than half an hour of primary characterization, the exhaust was exposed to black light continuously for $5 \mathrm{~h}$. The formed SOA was characterized for another 2 to $3 \mathrm{~h}$ after the black lamps were switched off to correct the particles' wall loss. OH precursor and seed particles were not introduced in this study.

An array of instruments was used to characterize gasand particle-phase compounds in the reactor. Gas-phase $\mathrm{NO}_{x}, \mathrm{O}_{3}$, and $\mathrm{SO}_{2}$ were measured with dedicated monitors (EC9810, 9841T, Ecotech, Australia, and Thermo Scientific model 43iTLE, USA). The detection limit and accuracy of the $\mathrm{SO}_{2}$ instrument are $0.2 \mathrm{ppb}$ and $\pm 1 \%$, respectively. Methane and $\mathrm{CO}$ concentrations were determined using a gas chromatograph (Agilent 6980GC, USA) with a flame ionization detector and a packed column (5A molecular sieve 60/80 mesh, $3 \mathrm{~m} \times 1 / 8$ in.) (Zhang et al., 2012). $\mathrm{CO}_{2}$ was analyzed with a HP 4890D gas chromatograph (Yi et al., 2007). Gasphase organic species were measured with a model 7100 preconcentrator (Entech Instruments Inc., USA) coupled with an Agilent 5973N gas chromatograph-mass selective detector/flame ionization detector/electron capture detector (GCMSD/FID, Agilent Technologies, USA) (Wang and Wu, 2008; Zhang et al., 2010, 2012, 2013) and a commer- cial proton-transfer-reaction time-of-flight mass spectrometer (PTR-TOF-MS, model 2000, Ionicon Analytik GmbH, Austria) (Lindinger et al., 1998; Jordan et al., 2009). $\mathrm{C}_{2}-$ $\mathrm{C}_{3}$ and $\mathrm{C}_{4}-\mathrm{C}_{12}$ hydrocarbons were measured by GC-FID and GC-MSD, respectively. PTR-TOF-MS was used to determine the time-resolved concentrations of VOCs such as aromatics. The decay curve of toluene was used to derive the average hydroxyl radical $(\mathrm{OH})$ concentration during each experiment.

Particle number concentrations and size distributions were measured with a scanning mobility particle sizer (SMPS, TSI Incorporated, USA, classifier model 3080, CPC model 3775). An aerosol density of $1.4 \mathrm{~g} \mathrm{~cm}^{-3}$ was assumed to convert the particle volume concentration into the mass concentration (Zhang et al., 2005). A high-resolution timeof-flight aerosol mass spectrometer (HR-TOF-MS, Aerodyne Research Incorporated, USA) was used to measure the particle chemical compositions and nonrefractory PM mass (Jayne et al., 2000; DeCarlo et al., 2006). The instrument was operated in the high-sensitivity $\mathrm{V}$ mode and highresolution $\mathrm{W}$ mode alternatively every $2 \mathrm{~min}$. The toolkit Squirrel $1.51 \mathrm{H}$ was used to obtain time series of various mass components (sulfate, nitrate, ammonium, and organics). We used the toolkit Pika $1.1 \mathrm{H}$ to determine the average element ratios of organics, including $\mathrm{H}: \mathrm{C}, \mathrm{O}: \mathrm{C}$, and $\mathrm{N}: \mathrm{C}$ (Aiken et al., 2007, 2008). The contribution of gas-phase $\mathrm{CO}_{2}$ to the $m / z 44$ signal was corrected with measured $\mathrm{CO}_{2}$ concentrations. The HR-TOF-MS was calibrated using $300 \mathrm{~nm}$ monodisperse ammonium nitrate particles.

A summary of initial experimental conditions and final results is presented in Tables 2 and 3, respectively. Total wallloss-corrected OA varied from 17.8 to $91.4 \mu \mathrm{g} \mathrm{m}^{-3}$, which spans the typical urban PM concentrations in heavy polluted megacities with poor air quality. POA concentrations of the experiments ranged from 0.13 to $0.31 \mu \mathrm{g} \mathrm{m}^{-3}$ and are negligible compared with the formed SOA. Initial mixing ratios of non-methane hydrocarbons (NMHCs) in the reactor were between 2.2 and $4.3 \mathrm{ppm}$, much higher than typical urban conditions. The average $\mathrm{OH}$ concentrations during photooxidation ranged from 0.73 to $1.29 \times 10^{6}$ molecules $\mathrm{cm}^{-3}$, approximately 5 times lower than that during summer daytime (Seinfeld and Pandis, 1998). Initial concentrations of the reactants were maintained as similar as possible for the same vehicle, though initial $\mathrm{NMHCs} \mathrm{NO}_{x}$, and average $\mathrm{OH}$ concentrations are different from typical urban conditions, so all 
Table 2. Summary of the initial conditions during the photooxidation of LDGV exhaust.

\begin{tabular}{lrrrrrrrr}
\hline Exp. no. & $\begin{array}{r}\mathrm{OH}\left(\times 10^{6}\right. \\
\left.\text { molecules cm }{ }^{-3}\right)\end{array}$ & $\begin{array}{r}T \\
\left({ }^{\circ} \mathrm{C}\right)\end{array}$ & $\begin{array}{r}\mathrm{RH} \\
(\%)\end{array}$ & $\mathrm{VOC} / \mathrm{NO}_{x}$ & $\begin{array}{r}\mathrm{NMHCs} \\
(\mathrm{ppbv})\end{array}$ & $\begin{array}{r}\mathrm{NO} \\
(\mathrm{ppbv})\end{array}$ & $\begin{array}{r}\mathrm{NO}_{2} \\
(\mathrm{ppbv})\end{array}$ & $\begin{array}{r}\mathrm{SO}_{2} \\
(\mathrm{ppbv})\end{array}$ \\
\hline I-1 & 0.88 & $25.0 \pm 0.8$ & $52.9 \pm 2.0$ & 9.3 & 2896 & 300.6 & 9.5 & 8.6 \\
I-2 & 1.19 & $25.5 \pm 0.3$ & $53.6 \pm 2.5$ & 7.7 & 2323 & 281.4 & 19.5 & 151.8 \\
I-3 & 1.45 & $23.9 \pm 0.9$ & $59.0 \pm 4.1$ & 7.9 & 2447 & 300.0 & 10.2 & 8.9 \\
II-1 & 1.29 & $24.6 \pm 0.5$ & $52.5 \pm 1.7$ & 10.8 & 4313 & 374 & 24.7 & 9 \\
II-2 & 1.08 & $24.2 \pm 0.7$ & $55.9 \pm 2.5$ & 9 & 3220 & 356 & 2.6 & 151.9 \\
III-1 & 0.73 & $24.1 \pm 0.6$ & $57.0 \pm 2.0$ & 6 & 2582 & 431 & 0.6 & 9.2 \\
III-2 & 0.79 & $24.3 \pm 0.3$ & $57.9 \pm 1.2$ & 4.9 & 2243 & 454.6 & 3.9 & 154.1 \\
\hline
\end{tabular}

a Photooxidation experiments of LDGV exhaust named with I, II, and III refer to different vehicles. ${ }^{b}$ Ammonium sulfate $\left(53.3 \mu \mathrm{g} \mathrm{m}^{-3}\right)$ was introduced as a seed aerosol.

Table 3. Summary of the final results during the photooxidation of LDGV exhaust.

\begin{tabular}{lrrrrrrr}
\hline Exp. no. & $\begin{array}{r}\text { POA } \\
\left(\mu \mathrm{g} \mathrm{m}^{-3}\right)\end{array}$ & $\begin{array}{r}\text { SOA } \\
\left(\mu \mathrm{g} \mathrm{m}^{-3}\right)\end{array}$ & $\begin{array}{r}\text { Sulfate } \\
\left(\mu \mathrm{g} \mathrm{m}^{-3}\right)\end{array}$ & $\begin{array}{r}\text { Ammonium } \\
\left(\mu \mathrm{g} \mathrm{m}^{-3}\right)\end{array}$ & $\begin{array}{r}\text { Nitrate } \\
\left(\mu \mathrm{g} \mathrm{m}^{-3}\right)\end{array}$ & $\begin{array}{r}\text { Particle number } \\
\left(\mathrm{cm}^{-3}\right)^{\mathrm{a}}\end{array}$ & $\begin{array}{r}{\left[\mathrm{H}^{+}\right]^{\mathrm{b}}} \\
\left(\mathrm{nmol} \mathrm{m}^{-3}\right)\end{array}$ \\
\hline I-1 & 0.31 & 77.6 & 0.7 & 17.1 & 65.9 & 85182 & 12.5 \\
I-2 & 0.21 & 91.2 & 67.5 & 17.6 & 6.1 & 563705 & 21.9 \\
II-1 & 0.28 & 30.7 & - & 2.6 & 5.6 & 7427 & 10.4 \\
II-2 & 0.13 & 37.3 & 38.1 & 9.7 & 1.9 & 357673 & 16.5 \\
III-1 & 0.17 & 17.6 & - & 0.1 & 0.7 & 116143 & 7.4 \\
III-2 & 0.23 & 77 & 76.7 & 19.2 & 5.3 & 630620 & 27.1 \\
\hline
\end{tabular}

${ }^{a}$ Maximum particle number concentrations were without wall loss corrections. ${ }^{b}$ The concentration of $\mathrm{H}^{+}$in particle phase shown here was the value when the SOA formation rate reached the maximum during each experiment.

changes in SOA mass could be attributed to the effects of $\mathrm{SO}_{2}$.

\subsection{SOA production factors}

The SOA production factor (PF) $\left(\mathrm{mg} \mathrm{kg}^{-1}\right)$ is calculated on a fuel basis:

$$
\begin{aligned}
\mathrm{PF} & =10^{6} \cdot[\mathrm{SOA}] \cdot\left(\frac{\left[\Delta \mathrm{CO}_{2}\right]}{\mathrm{MW}_{\mathrm{CO}_{2}}}+\frac{[\Delta \mathrm{CO}]}{\mathrm{MW}_{\mathrm{CO}}}+\frac{[\Delta \mathrm{HC}]}{\mathrm{MW}_{\mathrm{HC}}}\right)^{-1} \\
& \frac{\omega_{\mathrm{C}}}{\mathrm{MW}_{\mathrm{C}}}
\end{aligned}
$$

where $\left[\Delta \mathrm{CO}_{2}\right],[\Delta \mathrm{CO}]$, and $[\Delta \mathrm{HC}]$ are the backgroundcorrected concentrations of $\mathrm{CO}_{2}, \mathrm{CO}$, and the total hydrocarbons in the reactor in $\mu \mathrm{g} \mathrm{m}^{-3}$; [SOA] is the concentration of wall-loss-corrected SOA in $\mu \mathrm{g} \mathrm{m}^{-3}$; and $\mathrm{MW}_{\mathrm{CO}_{2}}, \mathrm{MW}_{\mathrm{CO}}$, $\mathrm{MW}_{\mathrm{HC}}$, and $\mathrm{MW}_{\mathrm{C}}$ are the molecular weights of $\mathrm{CO}_{2}, \mathrm{CO}$, $\mathrm{HC}$, and C. $\omega_{\mathrm{C}}(0.85)$ is the carbon intensity of the gasoline (Kirchstetter et al., 1999). Total hydrocarbons measured in this study include methane and $\mathrm{C}_{2}-\mathrm{C}_{12}$ hydrocarbons. The carbon content of each hydrocarbon was calculated and then summed in Eq. (1).

\subsection{Determination of $\mathrm{OH}$ concentration}

Decay of toluene measured by PTR-TOF-MS is used to determine the average $\mathrm{OH}$ concentration during each experi- ment. Changes in the toluene concentration over time can be expressed as

$\frac{\mathrm{d}[\text { toluene }]}{\mathrm{d} t}=-k \cdot[\mathrm{OH}] \cdot[$ toluene $]$,

where $k$ is the rate constant for the reaction between toluene and $\mathrm{OH}$ radical. The value of $k$ is obtained from the Master Chemical Mechanism version 3.3 (MCM v3.3, http://www. chem.leeds.ac.uk/MCM) (Jenkin et al., 2003). Assuming a constant $\mathrm{OH}$ concentration during an experiment, we can integrate Eq. (2) to get Eq. (3):

$\ln \left(\frac{[\text { toluene }]_{0}}{[\text { toluene }]_{t}}\right)=k \cdot[\mathrm{OH}] \cdot t$.

Thus, by plotting $\ln \left([\text { toluene }]_{0} /[\text { toluene }]_{t}\right)$ vs. time $t$, we can obtain a slope that equals $k \times[\mathrm{OH}]$. The average $\mathrm{OH}$ concentration is then calculated as

$[\mathrm{OH}]=\frac{\text { slope }}{k}$.

Average $\mathrm{OH}$ concentrations were determined when the black lamps were on. Segmented OH concentrations were also estimated (Fig. S1 in the Supplement) and listed in Table S1 for experiments with the addition of $\mathrm{SO}_{2}$. Similar concentrations of sCIs were determined subsequently (Sect. 2.5) when average and segmented $\mathrm{OH}$ concentrations were individually used for the same experiment. 


\subsection{Determination of the steady-state concentration of sCIs}

Ozonolysis of alkenes will form a primary ozonide through a 1,3-cycloaddition of ozone across the olefinic bond. The primary ozonide then rapidly decomposes to two carbonyl compounds, called excited CIs, which can be stabilized by collision to form sCIs (Heard et al., 2004; Johnson and Marston, 2008):

alkene $+\mathrm{O}_{3} \longrightarrow \phi$ sCIs + products

where $\phi$ represents the yield of sCIs from ozonolysis of alkenes. The four main losses of sCIs are reactions with $\mathrm{H}_{2} \mathrm{O}$, $\mathrm{SO}_{2}$, and $\mathrm{NO}_{2}$ and unimolecular decomposition.

sCIs $+\mathrm{H}_{2} \mathrm{O} \longrightarrow$ products,

sCIs $+\mathrm{SO}_{2} \longrightarrow \mathrm{SO}_{3}+$ products

sCIs $+\mathrm{NO}_{2} \longrightarrow$ products,

sCIs $\longrightarrow$ products.

The steady-state concentration of sCIs will be

$$
\begin{aligned}
& \text { sCIs }_{\text {steady }- \text { state }}= \\
& \frac{\phi K_{\mathrm{R} 1}\left[\mathrm{O}_{3}\right][\text { alkene }]}{K_{\mathrm{R} 2}\left[\mathrm{H}_{2} \mathrm{O}\right]+K_{\mathrm{R} 3}\left[\mathrm{SO}_{2}\right]+K_{\mathrm{R} 4}\left[\mathrm{NO}_{2}\right]+K_{\mathrm{R} 5}},
\end{aligned}
$$

where $K_{\mathrm{R} 1}$ is the rate coefficient for the ozonolysis of alkene; $K_{\mathrm{R} 2}, K_{\mathrm{R} 3}, K_{\mathrm{R} 4}$, and $K_{\mathrm{R} 5}$ represent the rate constant for reactions of sCIs with $\mathrm{H}_{2} \mathrm{O}, \mathrm{SO}_{2}, \mathrm{NO}_{2}$, and decomposition, respectively. This equation has been widely used to predict the steady-state concentration of sCIs in the atmosphere (Welz et al., 2012; Newland et al., 2015).

The steady-state concentration of sCIs throughout the entire experiment was estimated in this study. The production rate of sCIs was dependent on both the concentrations and composition of alkenes in the exhaust. Detailed gasphase mechanisms of alkenes from the MCM v3.3 were run to determine the time-resolved concentrations of sCIs in the experiments. The concentrations of alkenes included in the model and the category of sCIs are presented in Table 4. N-alkenes and branched alkenes respectively contributed $89.9-93.0 \%$ and $7.0-10.1 \%$ of the alkenes, with ethene and propene as two main components accounting for $66.8-81.3 \%$. Only the gas-phase mechanisms of alkenes were included in the model, with the concentrations of $\mathrm{OH}$ radicals, $\mathrm{SO}_{2}, \mathrm{O}_{3}$, and $\mathrm{NO}_{2}$ constrained to measured concentrations. Thus, neglecting alkanes and aromatics would not influence the steady-state concentrations of sCIs, as was confirmed by running the models including alkanes and aromatics. $K_{\mathrm{R} 2}, K_{\mathrm{R} 3}, K_{\mathrm{R} 4}$, and $K_{\mathrm{R} 5}$ for $\mathrm{CH}_{2} \mathrm{OO}, \mathrm{CH}_{3} \mathrm{CHOO}$, and $\left(\mathrm{CH}_{3}\right)_{2} \mathrm{COO}$ used in the model are listed in Table 5. The rate coefficients for other sCIs including $\mathrm{C}_{2} \mathrm{H}_{5} \mathrm{CHOO}$, $\mathrm{C}_{3} \mathrm{H}_{7} \mathrm{CHOO}, \mathrm{C}_{2} \mathrm{H}_{5}\left(\mathrm{CH}_{3}\right) \mathrm{COO}$, and $\left(\mathrm{CH}_{3}\right)_{2} \mathrm{CHCHOO}$ reacted with $\mathrm{H}_{2} \mathrm{O}, \mathrm{SO}_{2}$, and $\mathrm{NO}_{2}$, and their unimolecular decomposition were assumed to be same as $\mathrm{CH}_{2} \mathrm{OO}$. This assumption seems reasonable as the precursors of $\mathrm{C}_{2} \mathrm{H}_{5} \mathrm{CHOO}$,
$\mathrm{C}_{3} \mathrm{H}_{7} \mathrm{CHOO}, \mathrm{C}_{2} \mathrm{H}_{5}\left(\mathrm{CH}_{3}\right) \mathrm{COO}$, and $\left(\mathrm{CH}_{3}\right)_{2} \mathrm{CHCHOO}$ contributed only a small portion of alkenes in this study. The yields of $\mathrm{CH}_{2} \mathrm{OO}, \mathrm{CH}_{3} \mathrm{CHOO}$, and $\left(\mathrm{CH}_{3}\right)_{2} \mathrm{COO}$ used in the model were $0.37,0.38$, and 0.28 , respectively, while yields of other sCIs were assumed to be the same as $\mathrm{CH}_{2} \mathrm{OO}$.

\subsection{Wall loss corrections}

The loss of particles and organic vapors onto the reactor walls must be accounted for to accurately quantify the SOA production. A detailed discussion of these corrections can be found elsewhere (Liu et al., 2015). The loss of particles onto the walls was treated as a first-order process (McMurry and Grosjean, 1985). The wall loss rate constant was determined separately for each experiment by fitting the SMPS and AMS data with first-order kinetics when UV lamps were switched off. By applying this rate to the entire experiment, we use the same method as Pathak et al. (2007) to correct the wall loss of the particles. The wall loss of particles is a size-dependent process; therefore, the presence of nucleation would influence wall loss correction of the particles due to the rapid loss of nucleation-mode particles. As shown in a previous study, particle wall loss rates could not be accurately quantified for the particles generated in the nucleation event (Keywood et al., 2004). The impact of the nucleation event on wall loss estimate is considered to be negligible as less than $5 \%$ of the particle mass is in the nucleation-mode $20 \mathrm{~min}$ after nucleation for all experiments in this study.

Wall deposition of organic vapors can lead to the underestimation of SOA production (Matsunaga and Ziemann, 2010; X. Zhang et al., 2014, 2015). Wall deposition of a compound has recently been established as related to its volatility (X. Zhang et al., 2015). The extent that wall deposition of organic vapors impacts on SOA production depends on the competition of organic vapors depositing onto walls and suspended particles. Here, we assumed that gas-particle partitioning of organic vapors dominated their wall depositions and thus organic vapors were considered to only partition onto suspended particles.

As the collection efficiency of sulfate in the HR-TOFAMS can vary due to the coating of OA onto sulfate, we used AMS data combined with SMPS data to derive the timeresolved concentrations of $\mathrm{OA}$, sulfate, ammonium, and nitrate. The emission of black carbon (BC) from LDGVs was negligible according to a previous study (Liu et al., 2015); thus the ratio of OA to inorganic aerosols from the AMS was used to split the total particle mass measured by SMPS into the mass of OA, sulfate, ammonium, and nitrate (Gordon et al., 2014; Liu et al., 2015). 
Table 4. Concentrations of alkenes included in the model and the category of sCIs.

\begin{tabular}{lrrrl}
\hline \multirow{2}{*}{ Species } & \multicolumn{3}{l}{ Concentration $(\mathrm{ppb})$} & \multirow{2}{*}{ sCIs } \\
\cline { 2 - 4 } & $\mathrm{I}-2$ & $\mathrm{II}-2$ & $\mathrm{III}-2$ & \\
\hline Ethene & 333.1 & 113.8 & 202.0 & $\mathrm{CH}_{2} \mathrm{OO}$ \\
Propene & 95.8 & 50.3 & 52.6 & $\mathrm{CH}_{2} \mathrm{OO}, \mathrm{CH}_{3} \mathrm{CHOO}$ \\
1-Butene & 30.9 & 49.1 & 13.1 & $\mathrm{CH}_{2} \mathrm{OO}, \mathrm{C}_{2} \mathrm{H}_{5} \mathrm{CHOO}$ \\
cis-2-Butene & 7.6 & 4.8 & 7.1 & $\mathrm{CH}_{3} \mathrm{CHOO}$ \\
trans-2-Butene & 9.9 & 6.4 & 9.6 & $\mathrm{CH}_{3} \mathrm{CHOO}$ \\
1-Pentene & 3.8 & 0.3 & 3.1 & $\mathrm{CH}_{2} \mathrm{OO}, \mathrm{C}_{3} \mathrm{H}_{7} \mathrm{CHOO}$ \\
cis-2-Pentene & 5.2 & 1.2 & 5.2 & $\mathrm{CH}_{3} \mathrm{CHOO}, \mathrm{C}_{2} \mathrm{H}_{5} \mathrm{CHOO}$ \\
trans-2-Pentene & 8.5 & 2.6 & 9.4 & $\mathrm{CH}_{3} \mathrm{CHOO}, \mathrm{C}_{2} \mathrm{H}_{5} \mathrm{CHOO}$ \\
2-Methyl-1-butene & 11.9 & 5.4 & 12.4 & $\mathrm{CH}_{2} \mathrm{OO}, \mathrm{C}_{2} \mathrm{H}_{5}\left(\mathrm{CH}_{3}\right) \mathrm{COO}$ \\
3-Methyl-1-butene & 2.4 & 0.8 & 2.4 & $\mathrm{CH}_{2} \mathrm{OO},\left(\mathrm{CH}_{3}\right)_{2} \mathrm{CHCHOO}$ \\
2-Methyl-2-butene & 17.8 & 10.9 & 22.7 & $\left.\mathrm{CH}_{3} \mathrm{CHOO}, \mathrm{CH}_{3}\right)_{2} \mathrm{COO}$ \\
cis-2-Hexene & 0.8 & 0 & 1.5 & $\mathrm{CH}_{3} \mathrm{CHOO}, \mathrm{C}_{3} \mathrm{H}_{7} \mathrm{CHOO}$ \\
\hline
\end{tabular}

Table 5. Rate constants of sCIs used in the model.

\begin{tabular}{|c|c|c|c|c|}
\hline Stabilized CIs & $\begin{array}{r}10^{15} K_{\mathrm{R} 2} \\
\left(\mathrm{~cm}^{3} \text { molecule }\right. \\
-1 \\
\left.\mathrm{~s}^{-1}\right)\end{array}$ & $\begin{array}{r}10^{11} K_{\mathrm{R} 3} \\
\left(\mathrm{~cm}^{3} \text { molecule }{ }^{-1} \mathrm{~s}^{-1}\right)\end{array}$ & 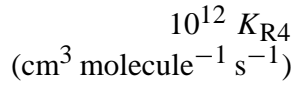 & $\begin{array}{r}K_{\mathrm{R} 5} \\
\left(\mathrm{~s}^{-1}\right)\end{array}$ \\
\hline $\mathrm{CH}_{2} \mathrm{OO}$ & $0.025^{\mathrm{a}}$ & $3.9^{\mathrm{b}}$ & $7.0^{\mathrm{b}}$ & $0^{\mathrm{c}}$ \\
\hline $\mathrm{CH}_{3} \mathrm{CHOO}$ & $7.0^{\mathrm{d}}$ & $4.55^{\mathrm{d}}$ & $2.0^{\mathrm{d}}$ & $67.5^{\mathrm{e}}$ \\
\hline$\left(\mathrm{CH}_{3}\right)_{2} \mathrm{COO}$ & $2.1^{\mathrm{c}}$ & $2.4^{\mathrm{c}}$ & $2.0^{\mathrm{c}}$ & $151^{\mathrm{c}}$ \\
\hline
\end{tabular}

${ }^{\mathrm{a}}$ Ouyang et al. (2013); ${ }^{\mathrm{b}}$ Welz et al. (2012); ${ }^{\mathrm{c}}$ Newland et al. (2015); ${ }^{\mathrm{d}}$ Taatjes et al. (2013); ${ }^{\mathrm{e}}$ average of $K_{\mathrm{R} 5}$ from Fenske et al. (2000) and Newland et al. (2015).

\section{Results and discussion}

\subsection{Formation of sulfate}

Figure 2 shows the temporal evolution of gas- and particlephase species during the photochemical aging of emissions from vehicle III with and without adding $\mathrm{SO}_{2}$. $\mathrm{NO}$ was injected to adjust the $\mathrm{VOC} / \mathrm{NO}_{x}$ ratio at approximately time $=$ $-0.25 \mathrm{~h}$ for both experiments. After the black lamps were switched on, NO was rapidly consumed in less than $1 \mathrm{~h}$. Mass concentrations of secondary aerosols rapidly increased following photooxidation with or without $\mathrm{SO}_{2}$ for approximately $1 \mathrm{~h}$, stabilizing after approximately $4 \mathrm{~h}$ of photooxidation (Figs. 2, 3, and 4). Substantial sulfate was formed synchronously with $\mathrm{OA}$ for experiments with $\mathrm{SO}_{2}$ with the maximum particle number concentrations at 5.4-48 times of those without $\mathrm{SO}_{2}$ (Table 1, Fig. 5), indicating enhanced new particle formation (NPF) when adding $\mathrm{SO}_{2}$. As the precursor of sulfuric acid $\left(\mathrm{H}_{2} \mathrm{SO}_{4}\right), \mathrm{SO}_{2}$ at higher concentrations would lead to additional formation of $\mathrm{H}_{2} \mathrm{SO}_{4}$, thereby increasing the nucleation rates and total particle number concentrations (Sipila et al., 2010). The S-bearing organic fragments $\mathrm{C}_{x} \mathrm{H}_{y} \mathrm{O}_{z} \mathrm{~S}$ determined by HR-TOF-AMS can be used as marker ions to quantify organosulfates (Huang et al., 2015). In this study the fragments $\mathrm{C}_{x} \mathrm{H}_{y} \mathrm{O}_{z} \mathrm{~S}$ were almost not appreciable. Using the methods of Huang et al. (2015), we estimated that the mass ratio of organosulfates to sulfate was less than $0.5 \%$. Thus the formation of organosulfates could be negligible in this study.

Substantial nitrates were formed for vehicles I and II (Figs. 3a and 4a) and could be attributed to ammonium or organic nitrates. The identification of ammonium and organic nitrates may be obtained from the $\mathrm{NO}^{+} / \mathrm{NO}_{2}^{+}$ratio, which is typically substantially higher for organic nitrates compared with ammonium nitrate (Farmer et al., 2010; Sato et al., 2010). The $\mathrm{NO}^{+} / \mathrm{NO}_{2}^{+}$ratios for experiments I-2 and II-2 were 1.99-2.60, within the range of 1.08-2.81 for ammonium nitrate (Farmer et al., 2010; Sato et al., 2010), suggesting that nitrates detected in the two experiments could be attributed to ammonium nitrate. Ammonium nitrate was likely formed by reactions of nitric acid formed from $\mathrm{NO}_{x}$ oxidation and ammonia, which is substantially higher in China's LDGV exhaust (Liu et al., 2014). The $\mathrm{NO}^{+} / \mathrm{NO}_{2}^{+}$ratios for experiments with $\mathrm{SO}_{2}$ were 3.9-5.0, significantly higher than ratios measured for ammonium nitrate and also similar to ratios for organic nitrates (3.82-5.84) from the photooxidation of aromatic hydrocarbons (Sato et al., 2010), indicating organic nitrates dominated nitrate formation in these experiments. High concentration of $\mathrm{SO}_{2}$ suppressed the formation of ammonium nitrate in experiments with $\mathrm{SO}_{2}$ as $\mathrm{NH}_{3}$ was liable to react with sulfuric acid rather than nitric acid (Pathak et al., 2009). 

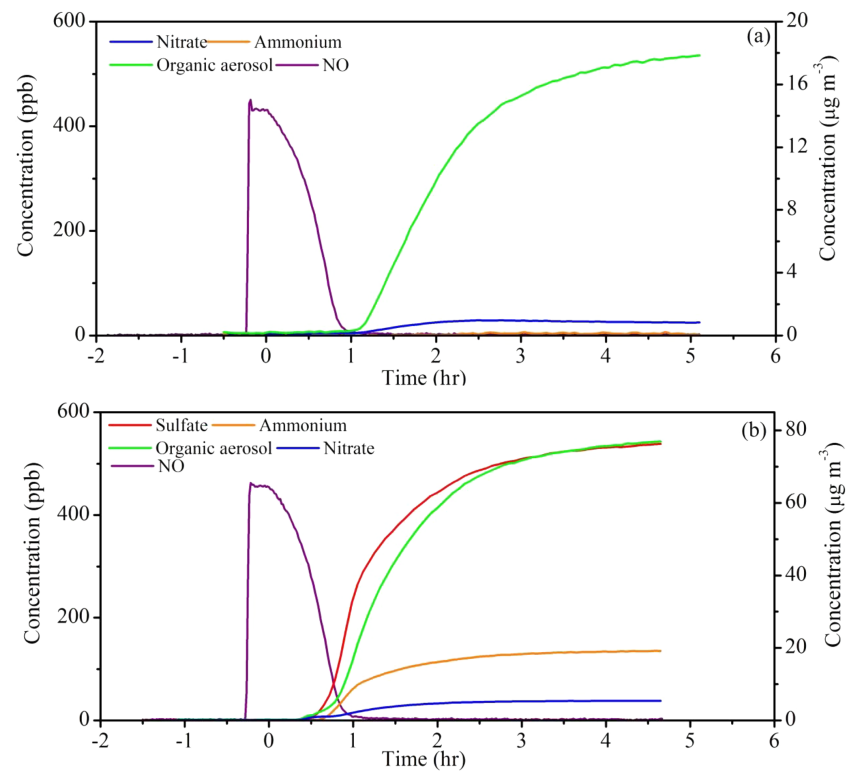

Figure 2. Concentration-time plots of NO (left $y$ axis) and particlephase species (right $y$ axis) during the photochemical aging of emissions from vehicle III. (a) Without and (b) with $\mathrm{SO}_{2}$. The concentrations of particle-phase species are wall-loss-corrected. At time $=0 \mathrm{~h}$, the black lamps were turned on.
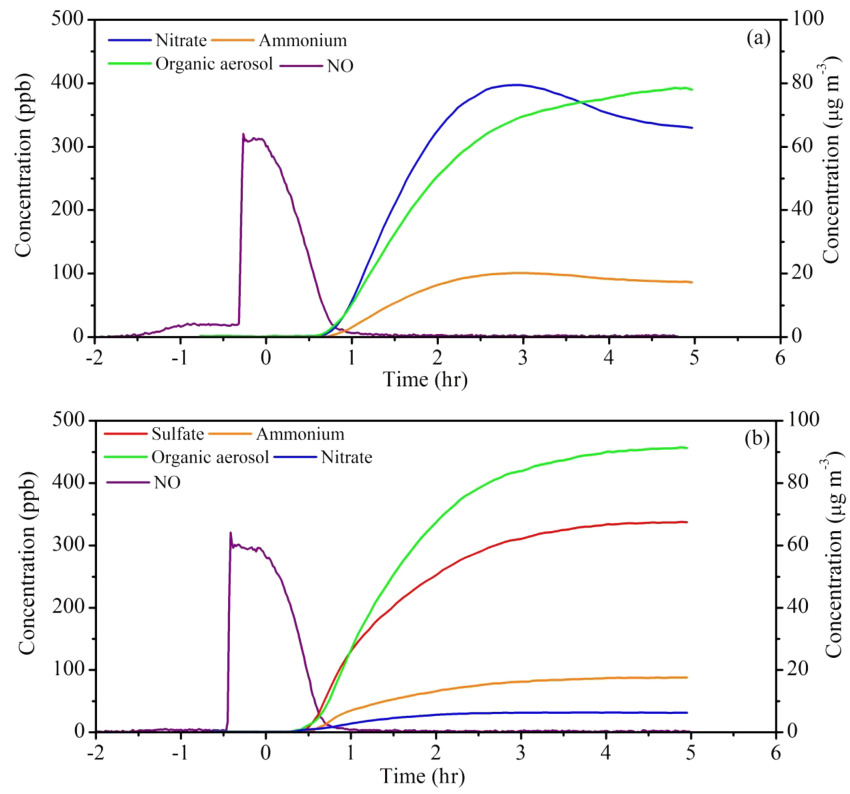

Figure 3. Concentration-time plots of NO (left $y$ axis) and particlephase species (right $y$ axis) during the photochemical aging of emissions from vehicle I. (a) Without and (b) with $\mathrm{SO}_{2}$. The concentrations of particle-phase species are wall-loss-corrected. At time $=0 \mathrm{~h}$, the black lamps were turned on.
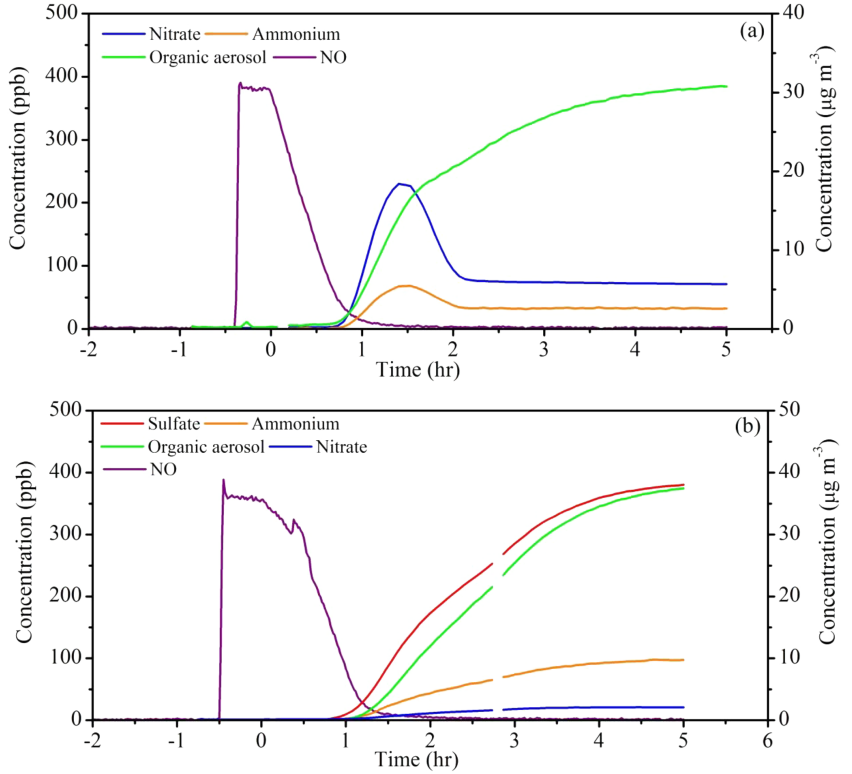

Figure 4. Concentration-time plots of NO (left $y$ axis) and particlephase species (right $y$ axis) during the photochemical aging of emissions from vehicle II. (a) Without $\mathrm{SO}_{2}$, and (b) with $\mathrm{SO}_{2}$. The concentrations of particle-phase species are wall-loss-corrected. At time $=0 \mathrm{~h}$, the black lamps were turned on.

Formation rates of sulfate, derived from the differential of concentration-time plots of sulfate, exhibited burst increases at the initial stage of sulfate formation and then decreased to near zero $5 \mathrm{~h}$ after sulfate formation initiated (Fig. 6a). The maximum formation rate of sulfate in experiments I-2, II-2, and III-2 was $61.5,21.6$, and $113 \mu \mathrm{g} \mathrm{m}^{-3} \mathrm{~h}^{-1}$, respectively, considerably higher than the rate of $0.17-0.37 \mathrm{ppbvh}^{-1}$ $\left(0.73-1.59 \mu \mathrm{g} \mathrm{m}^{-3} \mathrm{~h}^{-1}\right.$ under normal temperature and pressure (NTP) conditions) through gas-phase oxidation of $\mathrm{SO}_{2}$ during the daytime in the Pearl River Delta (PRD) region of China in the summer of 2006 (Xiao et al., 2009), and also more than 10 times higher than the maximum sulfate formation rate of $4.79 \mathrm{\mu g} \mathrm{m}^{-3} \mathrm{~h}^{-1}$ observed at an urban site in Beijing during the Beijing Olympic Games in 2008 (Zhang et al., 2011). The formation rate of sulfate was related to the concentrations of $\mathrm{SO}_{2}$ and $\mathrm{OH}$, which were respectively approximately 7 times higher and 2-16 times lower than those in the study of Xiao et al. (2009). Significant differences of sulfate formation rates between chamber and ambient observations could, however, indicate that there might be other processes dominating the oxidation of $\mathrm{SO}_{2}$ rather than gas-phase oxidation by $\mathrm{OH}$ in this study.

$\mathrm{SO}_{2}$ was typically deemed to be oxidized by $\mathrm{OH}$ radicals through homogeneous reactions in the gas phase (Calvert et al., 1978), or by $\mathrm{H}_{2} \mathrm{O}_{2}$ and $\mathrm{O}_{3}$ through in-cloud processes in the aqueous phase (Lelieveld and Heintzenberg, 1992), which, however, could be negligible in this study due to $\mathrm{RH}$ of approximate $50 \%$. As shown in Fig. 7, the loss rate of $\mathrm{SO}_{2}$ 


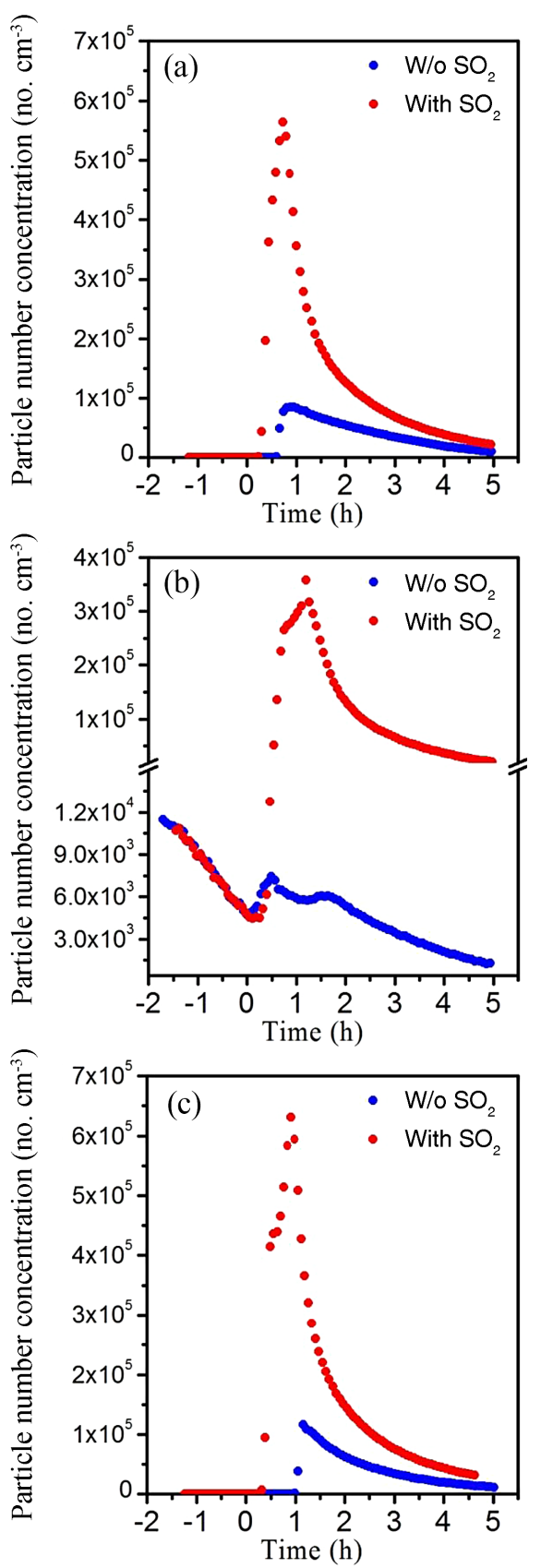

Figure 5. Evolution of particle number concentrations during the aging experiments of LDGV exhaust for vehicle I (a), II (b) and III (c). At time $=0 \mathrm{~h}$, the black lamps were turned on. "W/O $\mathrm{SO}_{2}$ " and "with $\mathrm{SO}_{2}$ " in the figures represent experiments without and with addition of $\mathrm{SO}_{2}$, respectively.

through homogeneous reactions with $\mathrm{OH}$ radicals in the three experiments ranged from 0.0023 to $0.0034 \mathrm{~h}^{-1}$, accounting for only $2.4-4.6 \%$ of the total loss rate of $\mathrm{SO}_{2}$. The initial concentrations of alkenes in the experiments with $\mathrm{SO}_{2}$ varied from 248 to $547 \mathrm{ppb}$, contributing $7.7-23.5 \%$ of the total NMHCs. The high content of alkenes in the exhaust might
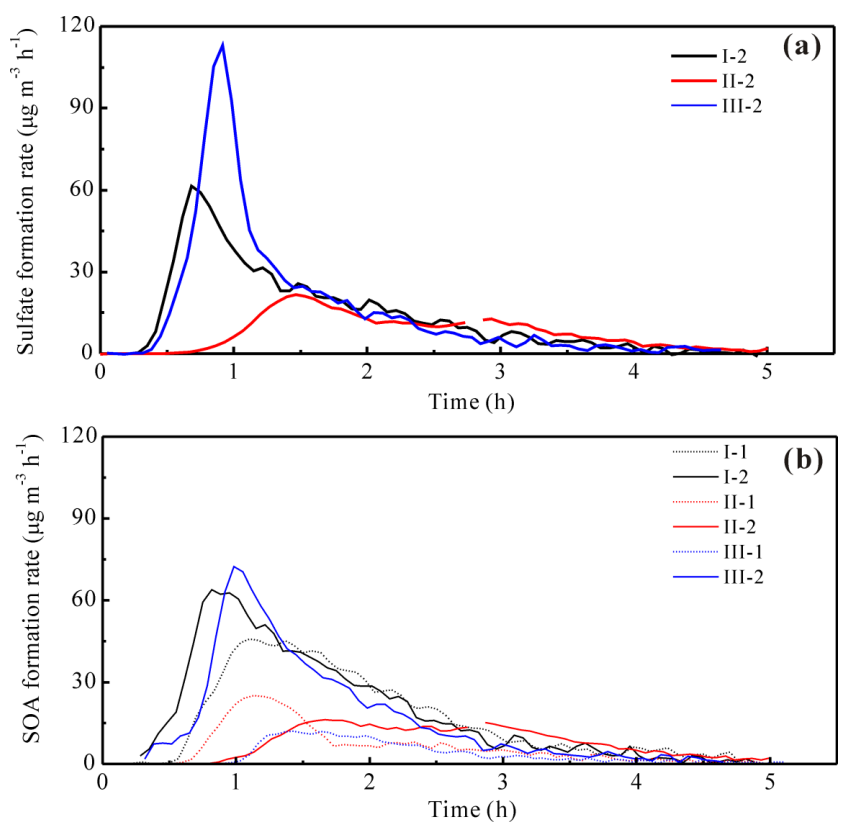

Figure 6. Sulfate formation rates (a) and SOA formation rates (b) as a function of time during the photooxidation of LDGV exhaust.

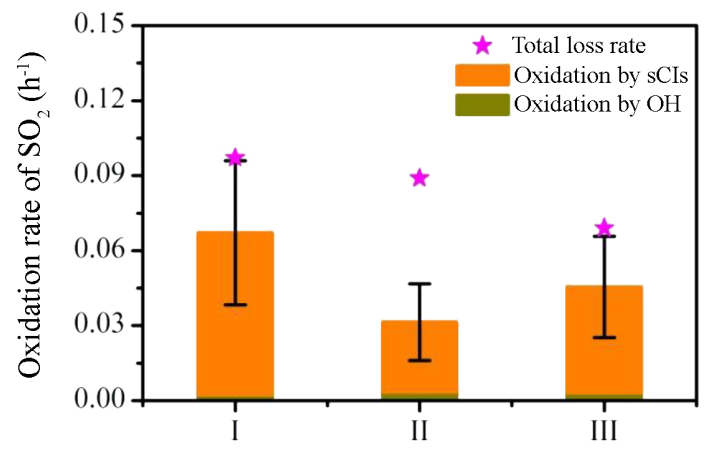

Figure 7. The oxidation rate of $\mathrm{SO}_{2}$ during the photooxidation of LDGV exhaust with $\mathrm{SO}_{2}$. The loss rates of $\mathrm{SO}_{2}$ reacting with $\mathrm{OH}$ radicals and sCIs were calculated by multiplying the reaction rate coefficients derived from the MCM v3.3 by the average $\mathrm{OH}$ concentration and estimated sCIs concentration, respectively. Error bars represent the standard deviation $(1 \sigma)$ of the oxidation rate of $\mathrm{SO}_{2}$ by $\mathrm{sCIs}$ throughout the whole experiment.

form a mass of sCIs through the reaction with ozone. Recent studies have indicated the rate coefficient of $\mathrm{CH}_{2} \mathrm{OO}$ with $\mathrm{SO}_{2}$ to be 50 to 10000 times larger than that used in tropospheric models (Welz et al., 2012). The oxidation of $\mathrm{SO}_{2}$ by sCIs may be as significant as that by $\mathrm{OH}$ radicals in the atmosphere. The oxidation rate of $\mathrm{SO}_{2}$ for experiments I-2 and III-2, through the reactions with sCIs, was calculated to be $0.065 \pm 0.029$ and $0.042 \pm 0.020 \mathrm{~h}^{-1}$ (Fig. 7), respectively, accounting for 66.9 and $61.4 \%$ of the total loss rate of $\mathrm{SO}_{2}$. Considering the variability of sCIs throughout the entire experiment, we concluded that sCIs were virtually responsible 
for the oxidation of $\mathrm{SO}_{2}$ in experiments $\mathrm{I}-2$ and III-2. The oxidation rate of $\mathrm{SO}_{2}$ through the reactions with sCIs for the experiment II- 2 was estimated to be $0.028 \pm 0.015 \mathrm{~h}^{-1}$, contributing $31.5 \%$ of the total loss rate of $\mathrm{SO}_{2}$. The unexplained loss of $\mathrm{SO}_{2}$ might be a result of heterogeneous oxidation in the presence of LDGV exhaust containing thousands of aerosols and gaseous species. He et al. (2014) found that $\mathrm{SO}_{2}$ could react with $\mathrm{NO}_{2}$ on the surface of mineral dust to promote the conversion of $\mathrm{SO}_{2}$ to sulfate. As shown in Fig. 5, the initial particle number for vehicle II was approximately $5000 \mathrm{~cm}^{-3}$, nearly $40-50$ times higher than for vehicle I and III, providing larger aerosol surface areas for the oxidation of $\mathrm{SO}_{2}$ by $\mathrm{NO}_{2}$. However, quantification of $\mathrm{SO}_{2}$ oxidation by $\mathrm{NO}_{2}$ on the surface of existing aerosols is difficult due to the lack of reaction rate constant (He et al., 2014). We speculate that the reaction between $\mathrm{SO}_{2}$ and $\mathrm{NO}_{2}$ on the surface of existing aerosols might explain the difference between the total loss rate of $\mathrm{SO}_{2}$ and the sum of sCIs and $\mathrm{OH}$ oxidation for vehicle II.

\subsection{SOA production}

Fuel-based SOA production factors (PFs), expressed as SOA production in milligrams $(\mathrm{mg})$ after $5 \mathrm{~h}$ photooxidation of LDGV exhaust emitted per kilogram $(\mathrm{kg})$ of gasoline burned, all increased substantially when adding $\mathrm{SO}_{2}$, 60-200\% above that without $\mathrm{SO}_{2}$ (Fig. 8a), although the selected cars' emission standards varied from Euro 1 to Euro 4. The in situ particle acidities at the time when SOA formation rate peaks were calculated as $\mathrm{H}^{+}$concentrations based on AIM-II model $\mathrm{H}^{+}-\mathrm{NH}_{4}^{+}-\mathrm{SO}_{4}^{2-}-\mathrm{NO}_{3}^{-}-\mathrm{H}_{2} \mathrm{O}$ with gasaerosol partitioning disabled (http://www.aim.env.uea.ac.uk/ aim/model2/model2a.php) (Clegg et al., 1998; Wexler and Clegg, 2002). Inputs to the model include temperature, $\mathrm{RH}$, $\left[\mathrm{SO}_{4}^{2-}\right],\left[\mathrm{NO}_{3}^{-}\right],\left[\mathrm{NH}_{4}^{+}\right]$, and $\left[\mathrm{H}^{+}\right]$total, calculated based on ion balance. $\mathrm{SO}_{4}^{2-}, \mathrm{NH}_{4}^{+}$and $\mathrm{NO}_{3}^{-}$contributed virtually all of the aerosol-phase ions mass in this study, thus determining the aerosol acidity. Though other ions (i.e., $\mathrm{Ca}^{2+}, \mathrm{Mg}^{2+}, \mathrm{K}^{+}$ and $\mathrm{Na}^{+}$) had a negligible influence on the aerosol acidity, it is worth noting that the reported values of $\mathrm{H}^{+}$may be the upper bound.

The in situ particle acidities with the addition of $\mathrm{SO}_{2}$ were 1.6-3.7 times as high as those without the addition of $\mathrm{SO}_{2}$ (Table 3). This elevated particle acidity could largely explain the higher PFs of SOA from LDGV exhaust with $\mathrm{SO}_{2}$, supported by the strong positive linear correlations $\left(R^{2}=0.965\right.$, $P<0.01)$ between SOA PFs and the in situ particle acidities (Fig. 8b). Aromatic hydrocarbons are vital SOA precursors in gasoline vehicle exhaust (Nordin et al., 2013; Gordon et al., 2014; Liu et al., 2015). The influence of particle acidity on SOA formation from aromatics is still debatable. Cao and Jang (2007) found that the presence of acid seeds with $\left[\mathrm{H}^{+}\right]$concentrations of $240-860 \mathrm{nmol} \mathrm{m}^{-3}$ significantly increased the SOA yields from oxidation of toluene and 1,3,5trimethylbenzene compared with yields using neutral seed

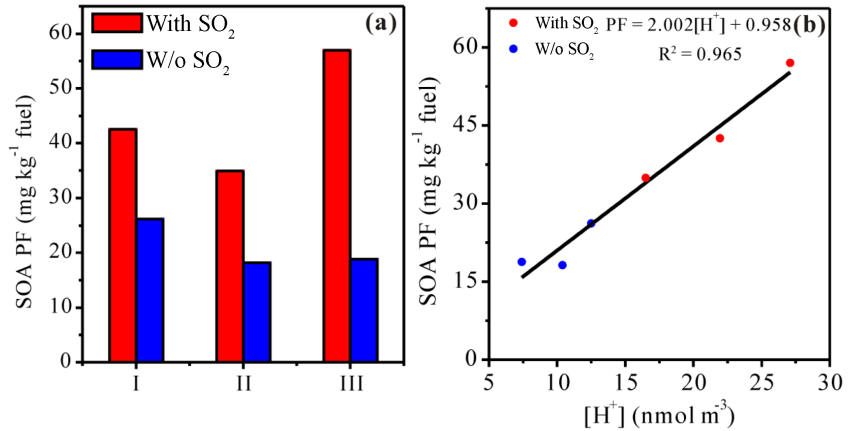

Figure 8. SOA production factor (PF) and its relationship with particle acidity. (a) SOA PF after $5 \mathrm{~h}$ of photochemical aging of exhaust from different LDGVs with and without additional $\mathrm{SO}_{2}$. (b) $\mathrm{SOA}$ $\mathrm{PF}$ as a function of in situ particle acidity. The concentration of $\mathrm{H}^{+}$ in the particle phase shown here was the value when the SOA formation rate reached the maximum during each experiment.

aerosols. However, Ng et al. (2007) observed no influence of particle acidity on SOA yields from the aromatics, possibly due to the low content of aerosol water. SOA production from gasoline vehicle exhaust was enhanced in this study, even at a low level of $\left[\mathrm{H}^{+}\right]$concentrations ranging from 7.4 to $27.1 \mathrm{nmol} \mathrm{m}^{-3}$. Gas-phase oxidation products of aromatic hydrocarbons in the exhaust, like multifunctional carbonyl glyoxal, would be transformed more rapidly into lowvolatility products through acid-catalyzed heterogeneous reactions (Jang et al., 2002; Cao and Jang, 2007) and thus caused increasing SOA production. Aerosol water is needed for the hydration of carbonyls and therefore influences the acid-catalyzed reactions. Liquid water content (LWC) in this study was not measured but instead predicted by the AIMII model, with an average value of $5.5 \pm 4.5 \mu \mathrm{g} \mathrm{m}^{-3}$ when SOA formation rate peaks, ensuring the occurrence of acidcatalyzed reactions. Figure 9 shows the ion intensity of fragment $m / z 88$ that can arise only from a glyoxal oligomer formed through acid-catalyzed heterogeneous reactions (Liggio et al., 2005). The scatter of the data might be due to the low intensity of $m / z$ 88. It may not be possible to take the low intensities of $m / z \quad 88$ as an indication that oligomers formed from glyoxal are not important. It is more likely that these fragments are thermally unstable at the vaporization temperature of HR-TOF-AMS $\left(600^{\circ} \mathrm{C}\right)$ and readily decompose to monomer or gem-diol forms before passing into the ionization region. The experiment with the addition of $\mathrm{SO}_{2}$, with higher particle acidity, exhibited relatively higher $\mathrm{m} / \mathrm{z} 88$ intensities. This indicated the important role of acidcatalyzed heterogeneous reactions in SOA formation from gasoline vehicle exhaust. A photooxidation experiment of exhaust from vehicle I in the presence of ammonium sulfate seeds $\left(53.3 \mu \mathrm{g} \mathrm{m}^{-3}\right)$ with RH of $59 \%$ (Table 2) was conducted to explore the effect of sulfate on SOA formation as particle acidity is typically driven by sulfate. The SOA production factor was $22.2 \mathrm{mg} \mathrm{kg}^{-1}$ fuel, comparable with 


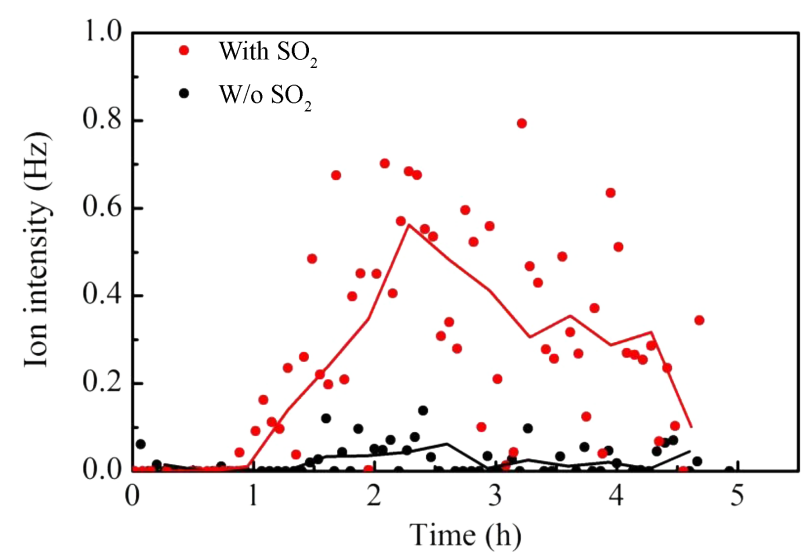

Figure 9. Time evolution of $m / z 88$ during the aging of LDGV exhaust from vehicle III. Solid lines are derived from the average values of every five data points.

$26.2 \mathrm{mg} \mathrm{kg}^{-1}$ fuel for experiment I-1, indicating that sulfate may not directly influence SOA production. Thus, the SOA production was indeed dependent on the particle acidity.

Recent studies have indicated that the presence of high concentrations of seed aerosols might decrease the loss of organic vapors to the walls and thus increase the SOA formation (Kroll et al., 2007; X. Zhang et al., 2014, 2015). However, Cocker et al. (2001) observed that the presence of ammonium sulfate seed aerosols had no impact on SOA formation from the photooxidation of $m$-xylene and 1,3,5trimethylbenzene. Li et al. (2015) also suggested that no measurable differences were observed in SOA formation from $m$-xylene between non-seeded and seeded experiments. In this study, comparable SOA PFs for experiments with and without seed aerosols indicated that wall loss of organic vapors did not significantly impact SOA production from gasoline vehicle exhaust.

SOA formation rates, derived from the differential of concentration-time plots of SOA, exhibited similar trends to sulfate with a burst increase at the initial stage of SOA formation (Fig. 6b). The average SOA formation rates for vehicles I, II, and III with $\mathrm{SO}_{2}$ were $1.1,1.2$, and 4.4 times as high as those without $\mathrm{SO}_{2}$, respectively, although the maximum rate for vehicle II with $\mathrm{SO}_{2}$ was lower. Here we particularly focused on the burst increase stage of SOA and sulfate, which may be related to fast increase in $\mathrm{PM}_{2.5}$ and occurrence of haze (He et al., 2014). Figure 10 shows the correlation between SOA formation rate and particle acidity. Plotted data corresponded to data selected from Fig. 6 when SOA formation rate was higher than zero to when the rate reached the maximum value. Significant linear correlations $(P<0.05$, $R^{2}>0.88$ ) between SOA formation rate and particle acidity during this stage for experiments with $\mathrm{SO}_{2}$ suggest that acidcatalyzed heterogeneous reactions might play an important role in the rapid formation of SOA (Jang et al., 2002). The fitted slopes for vehicle I, II, and III were 3.96, 0.82, and
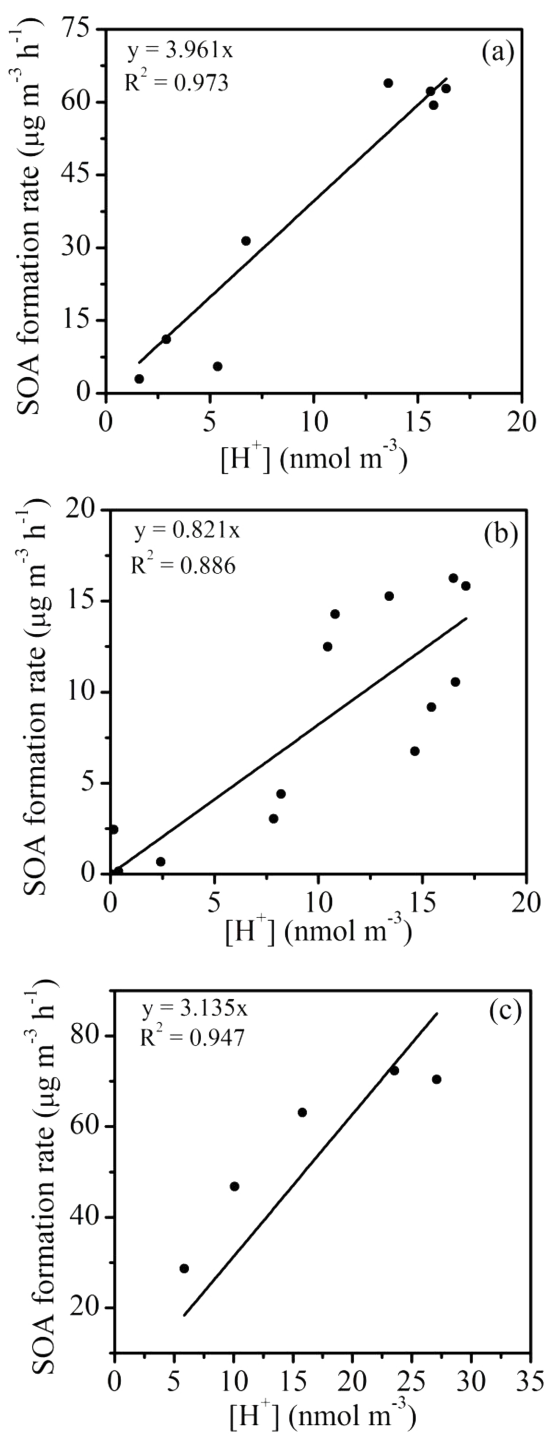

Figure 10. SOA formation rate as a function of in situ particle acidity $\left(\left[\mathrm{H}^{+}\right]\right)$for vehicle I (a), vehicle II (b), and vehicle III (c) with addition of $\mathrm{SO}_{2}$. Plotted data were selected from when SOA formation rate was higher than zero to when the rate reached the maximum value.

3.14, respectively, suggesting other factors, including alkene abundance, may influence the SOA formation rate. The initial concentration of alkenes for experiments I-2, II-2, and III-2 was 547,248 , and $353 \mathrm{ppb}$, respectively, consistent with the variation of the slopes. Higher alkene content would increase the formation rate of sCIs, which could rapidly oxidize $\mathrm{SO}_{2}$ to sulfuric acid, thus influencing the aerosol acidity.

\subsection{Oxidation state}

After $5 \mathrm{~h}$ of photooxidation, SOA's molar ratios of oxygen to carbon $(\mathrm{O}: \mathrm{C})$ and hydrogen to carbon $(\mathrm{H}: \mathrm{C})$ resolved by HR-TOF-AMS were plotted on a Van Krevelen diagram 


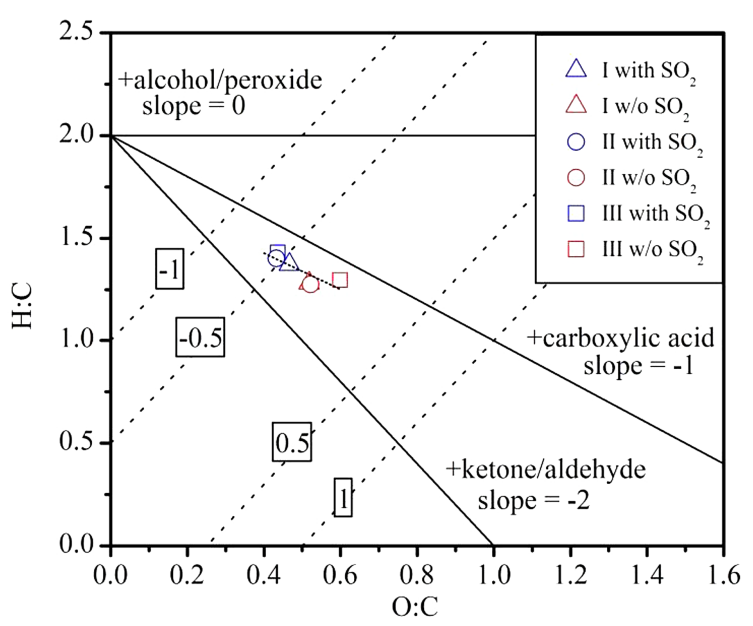

Figure 11. O : C vs. $\mathrm{H}$ : $\mathrm{C}$ of SOA formed from LDGV exhaust with and without additional $\mathrm{SO}_{2}$ at the end of each experiment. Blue and red symbols represent data with and without additional $\mathrm{SO}_{2}$, respectively. The dashed lines represent estimated average carbon oxidation states of $-1,-0.5,0.5$, and 1 (Kroll et al., 2011). The black lines represent the addition of functional groups to an aliphatic carbon (Heald et al., 2010).

(Heald et al., 2010) in Fig. 11. Concentrations of POA were lower than $0.5 \mu \mathrm{g} \mathrm{m}^{-3}$, typically regarded as not appreciable (Presto et al., 2014) and insufficient to determine the initial $\mathrm{H}: \mathrm{C}$ and $\mathrm{O}: \mathrm{C}$; thus only SOA data were plotted on the diagram. Relatively lower $\mathrm{O}: \mathrm{C}(0.44 \pm 0.02)$ and higher $\mathrm{H}: \mathrm{C}$ $(1.40 \pm 0.03)$ for the mixture of $\mathrm{SO}_{2}$ and exhaust were observed than for exhaust alone. The oxidation state of carbon $\left(\mathrm{OS}_{\mathrm{c}}\right)$, estimated from $\mathrm{O}: \mathrm{C}$ and $\mathrm{H}: \mathrm{C}$, can be used to describe the chemistry and oxidative evolution of atmospheric organic aerosols (Kroll et al., 2011). Further calculated $\mathrm{OS}_{\mathrm{c}}$ revealed an average lower level of $-0.51 \pm 0.06$ for SOA formed from LDGV exhaust with $\mathrm{SO}_{2}$ when compared to that of $-0.19 \pm 0.08$ without $\mathrm{SO}_{2}$, with all within or near the $\mathrm{OS}_{\mathrm{c}}$ range of $-0.5-0$ for semi-volatile oxygenated $\mathrm{OA}(\mathrm{SV}-$ OOA) (Aiken et al., 2008). The relatively lower $\mathrm{OS}_{\mathrm{c}}$ with $\mathrm{SO}_{2}$ indicated a lower oxidation degree of SOA. A difference in $\mathrm{H}: \mathrm{C}$ and $\mathrm{O}: \mathrm{C}$ for $m$-xylene SOA with neutral and acidic seed particles was not observed by Loza et al. (2012); thus acid-catalyzed heterogeneous reactions may not have influenced the oxidation degree of SOA in this study. Shilling et al. (2009) observed a lower O:C of SOA formed from the dark ozonolysis of $\alpha$-pinene at a higher mass loading of organic aerosols and suggested that compounds partitioning into the particle phase at lower loadings were more oxygenated. Kang et al. (2011) also observed that the oxidation degree of OA decreased rapidly as the OA mass concentration increased for the same amount of $\mathrm{OH}$ exposure. Given that the average $\mathrm{OH}$ concentrations were similar for the same vehicle (Table 2), the relative higher mass loading of $\mathrm{OA}$ in the experiments with $\mathrm{SO}_{2}$ may lead to the lower $\mathrm{O}: \mathrm{C}$ and thus decrease the oxidation degree of $\mathrm{OA}$. The $\mathrm{O}: \mathrm{C}$ ratios were observed to decrease 0.1 with an increase of approximately $50 \mu \mathrm{g} \mathrm{m}^{-3}$ of OA concentrations for $m$-xylene and $p$ xylene (Kang et al., 2011). However, in this study the slope was $0.1 \Delta \mathrm{O}: \mathrm{C}$ for approximately $26 \mu \mathrm{g} \mathrm{m}^{-3} \Delta \mathrm{OA}$. The differences may be due to some other precursors than aromatics contributing to SOA formation from gasoline vehicle exhaust (Liu et al., 2015).

The slope of -0.87 (Fig. 11) for the mixture of $\mathrm{SO}_{2}$ and exhaust, slightly higher than for exhaust alone (Liu et al., 2015), indicates that SOA formation in these experiments is a combination of carboxylic acid and alcohol/peroxide formation (Heald et al., 2010; $\mathrm{Ng}$ et al., 2011). The slope of -0.87 and intercept of approximately 1.8 are similar to the observation for ambient data with a slope of approximately -1 and intercept of approximately 1.8 (Heald et al., 2010), suggesting that $\mathrm{SOA}$ chemistry for the mixture of $\mathrm{SO}_{2}$ and gasoline vehicle exhaust is atmospherically relevant.

\section{Conclusions}

A series of chamber experiments investigating the formation of secondary aerosols from the mixture of $\mathrm{SO}_{2}$ and gasoline vehicle exhaust were conducted. The high content of alkenes in gasoline vehicle exhaust formed numerous sCIs, dominating the formation of sulfate, while elevated particle acidity, resulting from the formation of sulfuric acid, enhanced SOA production from the gasoline vehicle exhaust. We conclude that $\mathrm{SO}_{2}$ and gasoline vehicle exhaust can enhance each other in forming secondary aerosols. High concentration of $\mathrm{SO}_{2}$ and high levels of aerosol acidity combined with rapid increase in LDGVs in heavily polluted cities such as Beijing (Pathak et al., 2009; He et al., 2014) might consequently worsen the air quality in the absence of stricter control strategies on emissions of $\mathrm{SO}_{2}$ and vehicle exhaust. Previous studies have indicated that a high content of alkenes in China's gasoline oil is detrimental for the control of ozone in ambient air (Y. Zhang et al., 2013, 2015). Our results suggested that the incomplete combustion of gasoline with a high content of alkenes might also induce the formation of sCIs, facilitating the production of secondary aerosols. The limit of alkenes content in China was lowered to $24 \%$ by volume in the newly established Level $\mathrm{V}$ gasoline fuel standard from $28 \%$ by volume in the Level IV gasoline fuel standard. This limit remains substantially higher when compared to those limits in the USA or in Europe and, in particular, 6 times higher than that in California, USA. Thus, limiting the content of alkenes in China's gasoline might benefit the control of both ozone and secondary aerosols.

\section{The Supplement related to this article is available online at doi:10.5194/acp-16-675-2016-supplement.}


Acknowledgements. This study was supported by Strategic Priority Research Program of the Chinese Academy of Sciences (grant no. XDB05010200), the Ministry of Science and Technology of China (project no. 2012IM030700), the National Natural Science Foundation of China (project no. 41025012/41121063), and the Guangzhou Institute of Geochemistry (GIGCAS 135 project Y234161001).

Edited by: D. Farmer

\section{References}

Aiken, A. C., DeCarlo, P. F., and Jimenez, J. L.: Elemental Analysis of Organic Species with Electron Ionization HighResolution Mass Spectrometry, Anal. Chem., 79, 8350-8358, doi:10.1021/ac071150w, 2007.

Aiken, A. C., DeCarlo, P. F., Kroll, J. H., Worsnop, D. R., Huffman, J. A., Docherty, K. S., Ulbrich, I. M., Mohr, C., Kimmel, J. R., Sueper, D., Sun, Y., Zhang, Q., Trimborn, A., Northway, M., Ziemann, P. J., Canagaratna, M. R., Onasch, T. B., Alfarra, M. R., Prevot, A. S. H., Dommen, J., Duplissy, J., Metzger, A., Baltensperger, U., and Jimenez, J. L.: O / C and OM / OC Ratios of Primary, Secondary, and Ambient Organic Aerosols with HighResolution Time-of-Flight Aerosol Mass Spectrometry, Environ. Sci. Technol., 42, 4478-4485, doi:10.1021/es703009q, 2008.

Andreae, M. O., Jones, C. D., and Cox, P. M.: Strong present-day aerosol cooling implies a hot future, Nature, 435, 1187-1190, 2005.

Berglen, T. F., Berntsen, T. K., Isaksen, I. S. A., and Sundet, J. K.: A global model of the coupled sulfur/oxidant chemistry in the troposphere: The sulfur cycle, J. Geophys. Res.-Atmos., 109, D19310, doi:10.1029/2003JD003948, 2004.

Calvert, J. G., Su, F., Bottenheim, J. W., and Strausz, O. P.: Mechanism of the homogeneous oxidation of sulfur dioxide in the troposphere, Atmos. Environ., 12, 197-226, doi:10.1016/00046981(78)90201-9, 1978.

Cao, G. and Jang, M.: Effects of particle acidity and UV light on secondary organic aerosol formation from oxidation of aromatics in the absence of $\mathrm{NO}_{x}$, Atmos. Environ., 41, 7603-7613, doi:10.1016/j.atmosenv.2007.05.034, 2007.

Clegg, S. L., Brimblecombe, P., and Wexler, A. S.: Thermodynamic Model of the System $\mathrm{H}^{+}-\mathrm{NH}_{4}^{+}-\mathrm{SO}_{4}^{2-}-\mathrm{NO}_{3}^{-}-\mathrm{H}_{2} \mathrm{O}$ at Tropospheric Temperatures, J. Phys. Chem. A, 102, 2137-2154, doi:10.1021/jp973042r, 1998.

Cocker III, D. R., Mader, B. T., Kalberer, M., Flagan, R. C., and Seinfeld, J. H.: The effect of water on gas-particle partitioning of secondary organic aerosol: II. m-xylene and 1,3,5trimethylbenzene photooxidation systems, Atmos. Environ., 35, 6073-6085, doi:10.1016/S1352-2310(01)00405-8, 2001.

DeCarlo, P. F., Kimmel, J. R., Trimborn, A., Northway, M. J., Jayne, J. T., Aiken, A. C., Gonin, M., Fuhrer, K., Horvath, T., Docherty, K. S., Worsnop, D. R., and Jimenez, J. L.: Field-Deployable, High-Resolution, Time-of-Flight Aerosol Mass Spectrometer, Anal. Chem., 78, 8281-8289, doi:10.1021/ac061249n, 2006.

de Gouw, J. A., Middlebrook, A. M., Warneke, C., Goldan, P. D., Kuster, W. C., Roberts, J. M., Fehsenfeld, F. C., Worsnop, D. R., Canagaratna, M. R., Pszenny, A. A. P., Keene, W. C., Marchewka, M., Bertman, S. B., and Bates, T. S.: Budget of or- ganic carbon in a polluted atmosphere: Results from the New England Air Quality Study in 2002, J. Geophys. Res.-Atmos., 110, D16305, doi:10.1029/2004JD005623, 2005.

Edney, E. O., Kleindienst, T. E., Jaoui, M., Lewandowski, M., Offenberg, J. H., Wang, W., and Claeys, M.: Formation of 2methyl tetrols and 2-methylglyceric acid in secondary organic aerosol from laboratory irradiated isoprene/ $\mathrm{NO}_{x} / \mathrm{SO}_{2} /$ air mixtures and their detection in ambient $\mathrm{PM}_{2.5}$ samples collected in the eastern United States, Atmos. Environ., 39, 5281-5289, doi:10.1016/j.atmosenv.2005.05.031, 2005.

Farmer, D. K., Matsunaga, A., Docherty, K. S., Surratt, J. D., Seinfeld, J. H., Ziemann, P. J., and Jimenez, J. L.: Response of an aerosol mass spectrometer to organonitrates and organosulfates and implications for atmospheric chemistry, P. Natl. Acad. Sci., 107, 6670-6675, doi:10.1073/pnas.0912340107, 2010.

Fenske, J. D., Hasson, A. S., Ho, A. W., and Paulson, S. E.: Measurement of Absolute Unimolecular and Bimolecular Rate Constants for $\mathrm{CH}_{3} \mathrm{CHOO}$ Generated by the trans-2-Butene Reaction with Ozone in the Gas Phase, J. Phys. Chem. A, 104, 9921-9932, doi:10.1021/jp0016636, 2000.

Gordon, T. D., Presto, A. A., May, A. A., Nguyen, N. T., Lipsky, E. M., Donahue, N. M., Gutierrez, A., Zhang, M., Maddox, C., Rieger, P., Chattopadhyay, S., Maldonado, H., Maricq, M. M., and Robinson, A. L.: Secondary organic aerosol formation exceeds primary particulate matter emissions for lightduty gasoline vehicles, Atmos. Chem. Phys., 14, 4661-4678, doi:10.5194/acp-14-4661-2014, 2014.

He, H., Wang, Y., Ma, Q., Ma, J., Chu, B., Ji, D., Tang, G., Liu, C., Zhang, H., and Hao, J.: Mineral dust and $\mathrm{NO}_{x}$ promote the conversion of $\mathrm{SO}_{2}$ to sulfate in heavy pollution days, Sci. Rep., 4, 4172, doi:10.1038/srep04172, 2014.

Heald, C. L., Jacob, D. J., Park, R. J., Russell, L. M., Huebert, B. J., Seinfeld, J. H., Liao, H., and Weber, R. J.: A large organic aerosol source in the free troposphere missing from current models, Geophys. Res. Lett., 32, L18809, do:10.1029/2005GL023831, 2005.

Heald, C. L., Kroll, J. H., Jimenez, J. L., Docherty, K. S., DeCarlo, P. F., Aiken, A. C., Chen, Q., Martin, S. T., Farmer, D. K., and Artaxo, P.: A simplified description of the evolution of organic aerosol composition in the atmosphere, Geophys. Res. Lett., 37, L08803, doi:10.1029/2010gl042737, 2010.

Heard, D. E., Carpenter, L. J., Creasey, D. J., Hopkins, J. R., Lee, J. D., Lewis, A. C., Pilling, M. J., Seakins, P. W., Carslaw, N., and Emmerson, K. M.: High levels of the hydroxyl radical in the winter urban troposphere, Geophys. Res. Lett., 31, L18112, doi:10.1029/2004GL020544, 2004.

Huang, D. D., Li, Y. J., Lee, B. P., and Chan, C. K.: Analysis of Organic Sulfur Compounds in Atmospheric Aerosols at the HKUST Supersite in Hong Kong Using HR-ToF-AMS, Environ. Sci. Technol., 49, 3672-3679, doi:10.1021/es5056269, 2015.

Jang, M., Czoschke, N. M., Lee, S., and Kamens, R. M.: Heterogeneous Atmospheric Aerosol Production by AcidCatalyzed Particle-Phase Reactions, Science, 298, 814-817, doi:10.1126/science.1075798, 2002.

Jaoui, M., Edney, E. O., Kleindienst, T. E., Lewandowski, M., Offenberg, J. H., Surratt, J. D., and Seinfeld, J. H.: Formation of secondary organic aerosol from irradiated $\alpha$-pinene/toluene/ $\mathrm{NO}_{x}$ mixtures and the effect of isoprene and sulfur dioxide, J. Geophys. Res.-Atmos., 113, D09303, doi:10.1029/2007JD009426, 2008. 
Jayne, J. T., Leard, D. C., Zhang, X., Davidovits, P., Smith, K. A., Kolb, C. E., and Worsnop, D. R.: Development of an Aerosol Mass Spectrometer for Size and Composition Analysis of Submicron Particles, Aerosol. Sci. Tech., 33, 49-70, doi:10.1080/027868200410840, 2000.

Jenkin, M. E., Saunders, S. M., Wagner, V., and Pilling, M. J.: Protocol for the development of the Master Chemical Mechanism, MCM v3 (Part B): tropospheric degradation of aromatic volatile organic compounds, Atmos. Chem. Phys., 3, 181-193, doi:10.5194/acp-3-181-2003, 2003.

Johnson, D. and Marston, G.: The gas-phase ozonolysis of unsaturated volatile organic compounds in the troposphere, Chem. Soc. Rev., 37, 699-716, doi:10.1039/B704260B, 2008.

Johnson, D., Utembe, S. R., Jenkin, M. E., Derwent, R. G., Hayman, G. D., Alfarra, M. R., Coe, H., and McFiggans, G.: Simulating regional scale secondary organic aerosol formation during the TORCH 2003 campaign in the southern UK, Atmos. Chem. Phys., 6, 403-418, doi:10.5194/acp-6-403-2006, 2006.

Jordan, A., Haidacher, S., Hanel, G., Hartungen, E., Mark, L., Seehauser, H., Schottkowsky, R., Sulzer, P., and Mark, T. D.: A high resolution and high sensitivity proton-transfer-reaction time-offlight mass spectrometer (PTR-TOF-MS), Int. J. Mass. Spectrom., 286, 122-128, 2009.

Kang, E., Toohey, D. W., and Brune, W. H.: Dependence of SOA oxidation on organic aerosol mass concentration and $\mathrm{OH}$ exposure: experimental PAM chamber studies, Atmos. Chem. Phys., 11, 1837-1852, doi:10.5194/acp-11-1837-2011, 2011.

Keywood, M. D., Varutbangkul, V., Bahreini, R., Flagan, R. C., and Seinfeld, J. H.: Secondary Organic Aerosol Formation from the Ozonolysis of Cycloalkenes and Related Compounds, Environ. Sci. Technol., 38, 4157-4164, doi:10.1021/es035363o, 2004.

Kirchstetter, T. W., Harley, R. A., Kreisberg, N. M., Stolzenburg, M. R., and Hering, S. V.: On-road measurement of fine particle and nitrogen oxide emissions from light- and heavy-duty motor vehicles, Atmos. Environ., 33, 2955-2968, doi:10.1016/S13522310(99)00089-8, 1999.

Kleindienst, T. E., Edney, E. O., Lewandowski, M., Offenberg, J. H., and Jaoui, M.: Secondary Organic Carbon and Aerosol Yields from the Irradiations of Isoprene and $\alpha$-Pinene in the Presence of $\mathrm{NO}_{x}$ and $\mathrm{SO}_{2}$, Environ. Sci. Technol., 40, 3807-3812, doi:10.1021/es052446r, 2006.

Kroll, J. H., Chan, A. W. H., Ng, N. L., Flagan, R. C., and Seinfeld, J. H.: Reactions of Semivolatile Organics and Their Effects on Secondary Organic Aerosol Formation, Environ. Sci. Technol., 41, 3545-3550, doi:10.1021/es062059x, 2007.

Kroll, J. H., Donahue, N. M., Jimenez, J. L., Kessler, S. H., Canagaratna, M. R., Wilson, K. R., Altieri, K. E., Mazzoleni, L. R., Wozniak, A. S., Bluhm, H., Mysak, E. R., Smith, J. D., Kolb, C. E., and Worsnop, D. R.: Carbon oxidation state as a metric for describing the chemistry of atmospheric organic aerosol, Nat. Chem., 3, 133-139, doi:10.1038/nchem.948, 2011.

Lelieveld, J. and Heintzenberg, J.: Sulfate Cooling Effect on Climate Through In-Cloud Oxidation of Anthropogenic $\mathrm{SO}_{2}$, Science, 258, 117-120, doi:10.1126/science.258.5079.117, 1992.

Li, L., Tang, P., and Cocker III, D. R.: Instantaneous nitric oxide effect on secondary organic aerosol formation from m-xylene photooxidation, Atmos. Environ., 119, 144-155, doi:10.1016/j.atmosenv.2015.08.010, 2015.
Liggio, J., Li, S.-M., and McLaren, R.: Heterogeneous Reactions of Glyoxal on Particulate Matter: Identification of Acetals and Sulfate Esters, Environ. Sci. Technol., 39, 1532-1541, doi:10.1021/es048375y, 2005.

Lindinger, W., Hansel, A., and Jordan, A.: On-line monitoring of volatile organic compounds at pptv levels by means of protontransfer-reaction mass spectrometry (PTR-MS) medical applications, food control and environmental research, Int. J. Mass Spectrometry., 173, 191-241, doi:10.1016/S0168-1176(97)00281-4, 1998.

Liu, T., Wang, X., Deng, W., Hu, Q., Ding, X., Zhang, Y., He, Q., Zhang, Z., Lü, S., Bi, X., Chen, J., and Yu, J.: Secondary organic aerosol formation from photochemical aging of light-duty gasoline vehicle exhausts in a smog chamber, Atmos. Chem. Phys., 15, 9049-9062, doi:10.5194/acp-15-9049-2015, 2015.

Liu, T. Y., Wang, X. M., Wang, B. G., Ding, X., Deng, W., Lü, S. J., and Zhang, Y. L.: Emission factor of ammonia $\left(\mathrm{NH}_{3}\right)$ from on-road vehicles in China: tunnel tests in urban Guangzhou, Environ. Res. Lett., 9, 064027, doi:10.1088/1748-9326/9/6/064027, 2014.

Loza, C. L., Chhabra, P. S., Yee, L. D., Craven, J. S., Flagan, R. C., and Seinfeld, J. H.: Chemical aging of $m$-xylene secondary organic aerosol: laboratory chamber study, Atmos. Chem. Phys., 12, 151-167, doi:10.5194/acp-12-151-2012, 2012.

Matsunaga, A. and Ziemann, P. J.: Gas-Wall Partitioning of Organic Compounds in a Teflon Film Chamber and Potential Effects on Reaction Product and Aerosol Yield Measurements, Aerosol Sci. Tech., 44, 881-892, doi:10.1080/02786826.2010.501044, 2010.

Mauldin III, R. L., Berndt, T., Sipila, M., Paasonen, P., Petaja, T., Kim, S., Kurten, T., Stratmann, F., Kerminen, V. M., and Kulmala, M.: A new atmospherically relevant oxidant of sulphur dioxide, Nature, 488, 193-196, doi:10.1038/nature11278, 2012.

McMurry, P. H. and Grosjean, D.: Gas and aerosol wall losses in Teflon film smog chambers, Environ. Sci. Technol., 19, 11761182, doi:10.1021/es00142a006, 1985.

Nel, A.: Air Pollution-Related Illness: Effects of Particles, Science, 308, 804-806, doi:10.1126/science.1108752, 2005.

Newland, M. J., Rickard, A. R., Alam, M. S., Vereecken, L., Munoz, A., Rodenas, M., and Bloss, W. J.: Kinetics of stabilised Criegee intermediates derived from alkene ozonolysis: reactions with $\mathrm{SO}_{2}, \mathrm{H}_{2} \mathrm{O}$ and decomposition under boundary layer conditions, Phys. Chem. Chem. Phys., 17, 4076-4088, doi:10.1039/C4CP04186K, 2015.

Ng, N. L., Kroll, J. H., Chan, A. W. H., Chhabra, P. S., Flagan, R. C., and Seinfeld, J. H.: Secondary organic aerosol formation from $m$-xylene, toluene, and benzene, Atmos. Chem. Phys., 7, 3909-3922, doi:10.5194/acp-7-3909-2007, 2007.

Ng, N. L., Canagaratna, M. R., Jimenez, J. L., Chhabra, P. S., Seinfeld, J. H., and Worsnop, D. R.: Changes in organic aerosol composition with aging inferred from aerosol mass spectra, Atmos. Chem. Phys., 11, 6465-6474, doi:10.5194/acp-11-64652011, 2011.

Nordin, E. Z., Eriksson, A. C., Roldin, P., Nilsson, P. T., Carlsson, J. E., Kajos, M. K., Hellén, H., Wittbom, C., Rissler, J., Löndahl, J., Swietlicki, E., Svenningsson, B., Bohgard, M., Kulmala, M., Hallquist, M., and Pagels, J. H.: Secondary organic aerosol formation from idling gasoline passenger vehicle emissions investigated in a smog chamber, Atmos. Chem. Phys., 13, 6101-6116, doi:10.5194/acp-13-6101-2013, 2013. 
Ouyang, B., McLeod, M. W., Jones, R. L., and Bloss, W. J.: $\mathrm{NO}_{3}$ radical production from the reaction between the Criegee intermediate $\mathrm{CH}_{2} \mathrm{OO}$ and $\mathrm{NO}_{2}$, Phys. Chem. Chem. Phys., 15, 17070-17075, doi:10.1039/C3CP53024H, 2013.

Parrish, D. D. and Zhu, T.: Clean Air for Megacities, Science, 326, 674-675, doi:10.1126/science.1176064, 2009.

Pathak, R. K., Stanier, C. O., Donahue, N. M., and Pandis, S. N.: Ozonolysis of alpha-pinene at atmospherically relevant concentrations: Temperature dependence of aerosol mass fractions (yields), J. Geophys. Res.-Atmos, 112, D03201, doi:10.1029/2006jd007436, 2007.

Pathak, R. K., Wu, W. S., and Wang, T.: Summertime $\mathrm{PM}_{2.5}$ ionic species in four major cities of China: nitrate formation in an ammonia-deficient atmosphere, Atmos. Chem. Phys., 9, 17111722, doi:10.5194/acp-9-1711-2009, 2009.

Platt, S. M., El Haddad, I., Zardini, A. A., Clairotte, M., Astorga, C., Wolf, R., Slowik, J. G., Temime-Roussel, B., Marchand, N., Ježek, I., Drinovec, L., Mocnik, G., Möhler, O., Richter, R., Barmet, P., Bianchi, F., Baltensperger, U., and Prévôt, A. S. H.: Secondary organic aerosol formation from gasoline vehicle emissions in a new mobile environmental reaction chamber, Atmos. Chem. Phys., 13, 9141-9158, doi:10.5194/acp-13-91412013, 2013.

Presto, A. A., Gordon, T. D., and Robinson, A. L.: Primary to secondary organic aerosol: evolution of organic emissions from mobile combustion sources, Atmos. Chem. Phys., 14, 5015-5036, doi:10.5194/acp-14-5015-2014, 2014.

Sato, K., Takami, A., Isozaki, T., Hikida, T., Shimono, A., and Imamura, T.: Mass spectrometric study of secondary organic aerosol formed from the photo-oxidation of aromatic hydrocarbons, Atmos. Environ., 44, 1080-1087, doi:10.1016/j.atmosenv.2009.12.013, 2010.

Seinfeld, J. and Pandis, S. N.: From air pollution to climate change, Atmospheric Chemistry and Physics, 2nd Edn., John Wiley, New York, USA, p. 208, 1998.

Shilling, J. E., Chen, Q., King, S. M., Rosenoern, T., Kroll, J. H., Worsnop, D. R., DeCarlo, P. F., Aiken, A. C., Sueper, D., Jimenez, J. L., and Martin, S. T.: Loading-dependent elemental composition of $\alpha$-pinene SOA particles, Atmos. Chem. Phys., 9, 771-782, doi:10.5194/acp-9-771-2009, 2009.

Shindell, D. T., Faluvegi, G., Koch, D. M., Schmidt, G. A., Unger, N., and Bauer, S. E.: Improved Attribution of Climate Forcing to Emissions, Science, 326, 716-718, doi:10.1126/science.1174760, 2009.

Sipila, M., Berndt, T., Petaja, T., Brus, D., Vanhanen, J., Stratmann, F., Patokoski, J., Mauldin, R. L., Hyvarinen, A. P., Lihavainen, H., and Kulmala, M.: The Role of Sulfuric Acid in Atmospheric Nucleation, Science, 327, 1243-1246, doi:10.1126/science.1180315, 2010.

Taatjes, C. A., Welz, O., Eskola, A. J., Savee, J. D., Scheer, A. M., Shallcross, D. E., Rotavera, B., Lee, E. P. F., Dyke, J. M., Mok, D. K. W., Osborn, D. L., and Percival, C. J.: Direct Measurements of Conformer-Dependent Reactivity of the Criegee Intermediate $\mathrm{CH}_{3} \mathrm{CHOO}$, Science, 340, 177-180, doi:10.1126/science.1234689, 2013.

Tkacik, D. S., Lambe, A. T., Jathar, S., Li, X., Presto, A. A., Zhao, Y. L., Blake, D., Meinardi, S., Jayne, J. T., Croteau, P. L., and Robinson, A. L.: Secondary Organic Aerosol Formation from in-Use Motor Vehicle Emissions Using a Potential
Aerosol Mass Reactor, Environ. Sci. Technol., 48, 11235-11242, doi:10.1021/es502239v, 2014.

Volkamer, R., Jimenez, J. L., San Martini, F., Dzepina, K., Zhang, Q., Salcedo, D., Molina, L. T., Worsnop, D. R., and Molina, M. J.: Secondary organic aerosol formation from anthropogenic air pollution: Rapid and higher than expected, Geophys. Res. Lett., 33, L17811, doi:10.1029/2006g1026899, 2006.

Wang, X. and Wu, T.: Release of Isoprene and Monoterpenes during the Aerobic Decomposition of Orange Wastes from Laboratory Incubation Experiments, Environ. Sci. Technol., 42, 3265-3270, doi:10.1021/es702999j, 2008.

Wang, X., Liu, T., Bernard, F., Ding, X., Wen, S., Zhang, Y., Zhang, Z., He, Q., Lü, S., Chen, J., Saunders, S., and Yu, J.: Design and characterization of a smog chamber for studying gas-phase chemical mechanisms and aerosol formation, Atmos. Meas. Tech., 7, 301-313, doi:10.5194/amt-7-301-2014, 2014.

Welz, O., Savee, J. D., Osborn, D. L., Vasu, S. S., Percival, C. J., Shallcross, D. E., and Taatjes, C. A.: Direct Kinetic Measurements of Criegee Intermediate $\left(\mathrm{CH}_{2} \mathrm{OO}\right)$ Formed by Reaction of $\mathrm{CH}_{2} \mathrm{I}$ with $\mathrm{O}_{2}$, Science, 335, 204-207, doi:10.1126/science.1213229, 2012.

Wexler, A. S. and Clegg, S. L.: Atmospheric aerosol models for systems including the ions $\mathrm{H}^{+}, \mathrm{NH}_{4}^{+}, \mathrm{Na}^{+}, \mathrm{SO}_{4}^{2-}$, $\mathrm{NO}_{3}^{-}, \mathrm{Cl}^{-}, \mathrm{Br}^{-}$, and $\mathrm{H}_{2} \mathrm{O}$, J. Geophys. Res., 107, 4207, doi:10.1029/2001JD000451, 2002.

Xiao, R., Takegawa, N., Kondo, Y., Miyazaki, Y., Miyakawa, T., Hu, M., Shao, M., Zeng, L. M., Hofzumahaus, A., Holland, F., Lu, K., Sugimoto, N., Zhao, Y., and Zhang, Y. H.: Formation of submicron sulfate and organic aerosols in the outflow from the urban region of the Pearl River Delta in China, Atmos. Environ., 43, 3754-3763, doi:10.1016/j.atmosenv.2009.04.028, 2009.

Yi, Z., Wang, X., Sheng, G., Zhang, D., Zhou, G., and Fu, J.: Soil uptake of carbonyl sulfide in subtropical forests with different successional stages in south China, J. Geophy. Res.-Atmos., 112, D08302, doi:10.1029/2006JD008048, 2007.

Zhang, Q., Worsnop, D. R., Canagaratna, M. R., and Jimenez, J. L.: Hydrocarbon-like and oxygenated organic aerosols in Pittsburgh: insights into sources and processes of organic aerosols, Atmos. Chem. Phys., 5, 3289-3311, doi:10.5194/acp-5-32892005, 2005.

Zhang, Q., Jimenez, J. L., Canagaratna, M. R., Allan, J. D., Coe, H., Ulbrich, I., Alfarra, M. R., Takami, A., Middlebrook, A M., Sun, Y. L., Dzepina, K., Dunlea, E., Docherty, K., DeCarlo, P. F., Salcedo, D., Onasch, T., Jayne, J. T., Miyoshi, T., Shimono, A., Hatakeyama, S., Takegawa, N., Kondo, Y., Schneider, J., Drewnick, F., Borrmann, S., Weimer, S., Demerjian, K., Williams, P., Bower, K., Bahreini, R., Cottrell, L., Griffin, R. J., Rautiainen, J., Sun, J. Y., Zhang, Y. M., and Worsnop, D. R.: Ubiquity and dominance of oxygenated species in organic aerosols in anthropogenically-influenced Northern Hemisphere midlatitudes, Geophys. Res. Lett., 34, L13801, doi:10.1029/2007g1029979, 2007.

Zhang, X., Cappa, C. D., Jathar, S. H., McVay, R. C., Ensberg, J. J., Kleeman, M. J., and Seinfeld, J. H.: Influence of vapor wall loss in laboratory chambers on yields of secondary organic aerosol, P. Natl. Acad. Sci., 111, 5802-5807, doi:10.1073/pnas.1404727111, 2014.

Zhang, X., Schwantes, R. H., McVay, R. C., Lignell, H., Coggon, M. M., Flagan, R. C., and Seinfeld, J. H.: Vapor wall deposi- 
tion in Teflon chambers, Atmos. Chem. Phys., 15, 4197-4214, doi:10.5194/acp-15-4197-2015, 2015.

Zhang, Y., Guo, H., Wang, X., Simpson, I. J., Barletta, B., Blake, D. R., Meinardi, S., Rowland, F. S., Cheng, H., Saunders, S. M., and Lam, S. H. M.: Emission patterns and spatiotemporal variations of halocarbons in the Pearl River Delta region, southern China, J. Geophy. Res.-Atmos., 115, D15309, doi:10.1029/2009JD013726, 2010.

Zhang, Y., Wang, X., Blake, D. R., Li, L., Zhang, Z., Wang, S., Guo, H., Lee, F. S. C., Gao, B., Chan, L., Wu, D., and Rowland, F. S.: Aromatic hydrocarbons as ozone precursors before and after outbreak of the 2008 financial crisis in the Pearl River Delta region, south China, J. Geophy. Res.-Atmos., 117, D15306, doi:10.1029/2011JD017356, 2012.
Zhang, Y., Wang, X., Zhang, Z., Lü, S., Shao, M., Lee, F. S. C., and Yu, J.: Species profiles and normalized reactivity of volatile organic compounds from gasoline evaporation in China, Atmos. Environ., 79, 110-118, doi:10.1016/j.atmosenv.2013.06.029, 2013.

Zhang, Y., Wang, X., Zhang, Z., Lü, S., Huang, Z., and Li, L.: Sources of $\mathrm{C}_{2}-\mathrm{C}_{4}$ alkenes, the most important ozone nonmethane hydrocarbon precursors in the Pearl River Delta region, Sci. Total Environ., 502, 236-245, doi:10.1016/j.scitotenv.2014.09.024, 2015.

Zhang, Y. M., Zhang, X. Y., Sun, J. Y., Lin, W. L., Gong, S. L., Shen, X. J., and Yang, S.: Characterization of new particle and secondary aerosol formation during summertime in Beijing, China Tellus B, 63, 382-394, doi:10.3402/tellusb.v63i3.16221, 2011. 